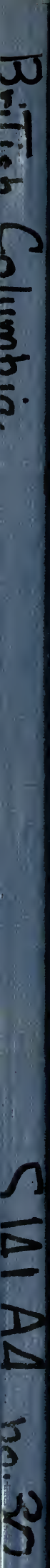

s 141 A4 no.30

$B$ 己 906574 


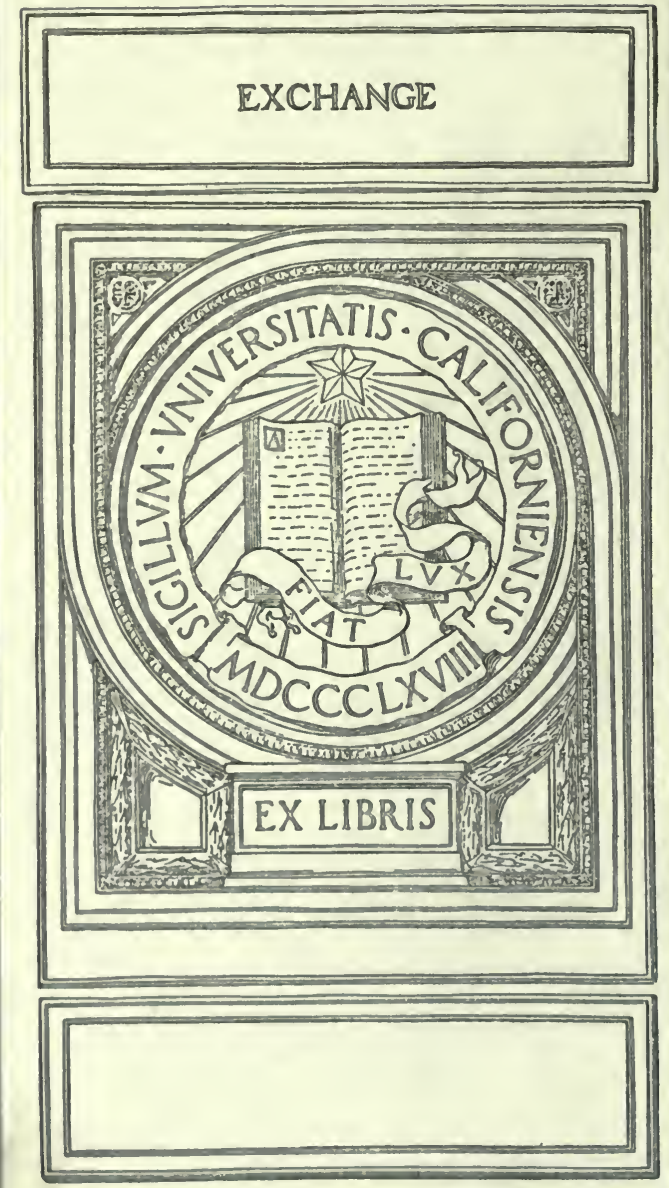



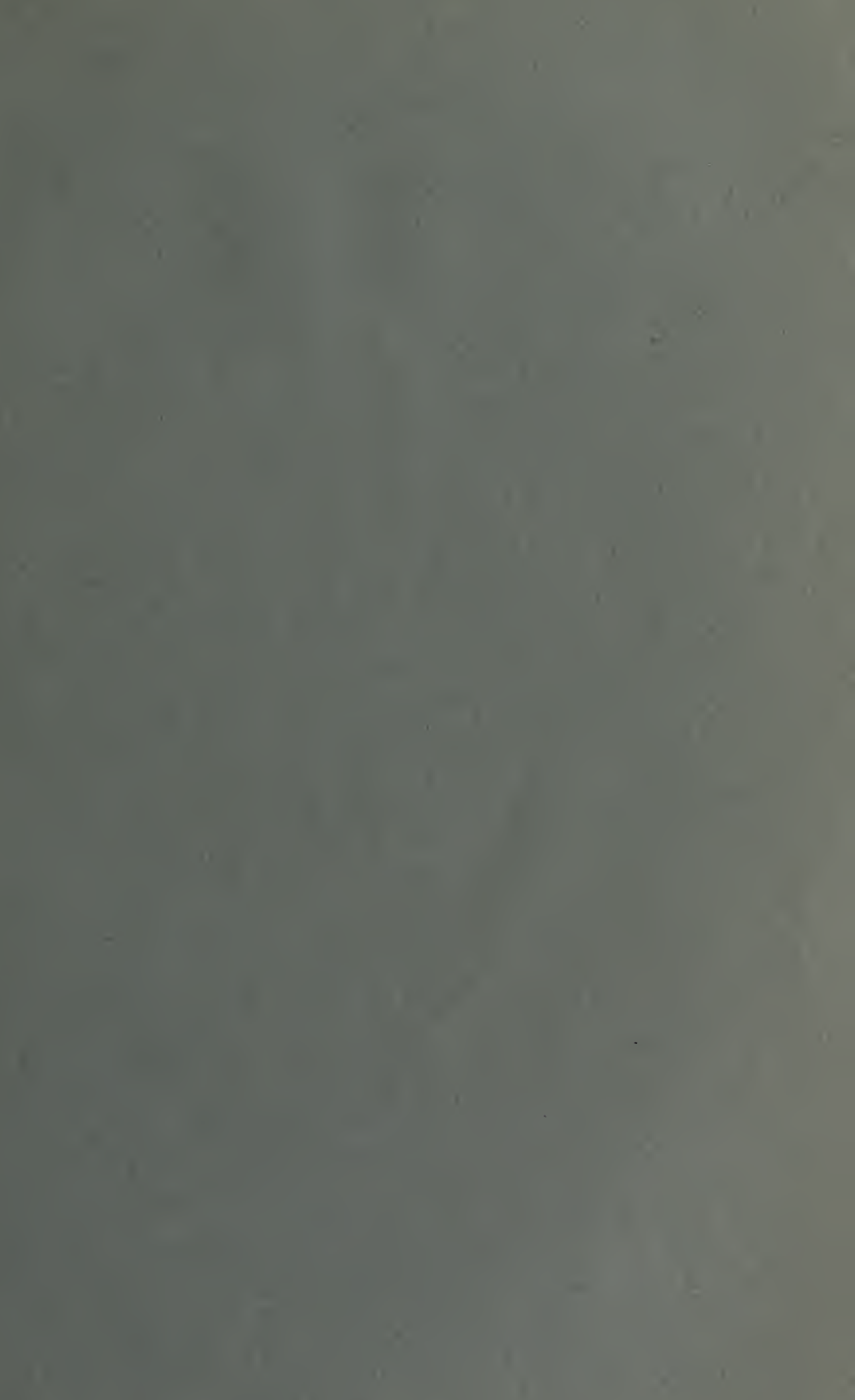



\section{DEPARTMENT OF AGRICULTURE.}

\section{BULLETIN No. 30. \\ GUIDE TO BEE-KEEPING}

\section{BRITISH COLUMBIA.}

F. DUNDAS TODD.

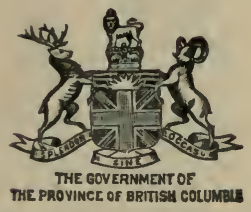

PRINTED BY AUTHORITY OF

THE LEGISLATIVE ASSEMBLY OF BRTTISH COLUMBIA.

VICTORIA, B. C. :

Printed by Rich 1911. 


\section{EXCEANGE}




\title{
DEPARTMENT OF AGRICULTURE.
}

\author{
BULLETIN No. 30.
}

\section{GUIDE TO BEE-KEEPING \\ $-\mathrm{x}-$}

\section{BRITISH COLUMBIA.}

F. DUNDAS TODD.

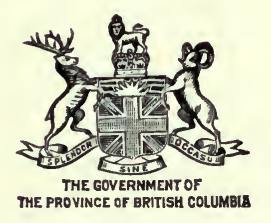

PRINTED BY AUTHORITY OF

THE LEGISLATIVE ASSEMBLY OF BRITISH COLUMBIA.

VICTORIA, B. C. :

Printed by Richard Wolfenden, I.S.O., V.D., Printer to the King's Most Excellent Majesty. 1911. 
IIonourable Price Ellison,

Minister of Agriculture,

Victoria, B. C. :

Sir,--I have the honour to transmit herewith Bulletin No. 30, entitled "Guide to Bee-keeping."

This Bulletin has been issued in order to meet the large demand for practical information concerning this most important branch of farming. The introductions contained therein are concise and practical, and adapterl to the conditions prevailing in British Columbia, and will, it is hoped, prove of benefit to those starting or at present engaged in this industry.

I have the honour to be,

Sir,

Your obedient servant,

WM. E. SCOTT,

Deputy Minister of Ariculture. 


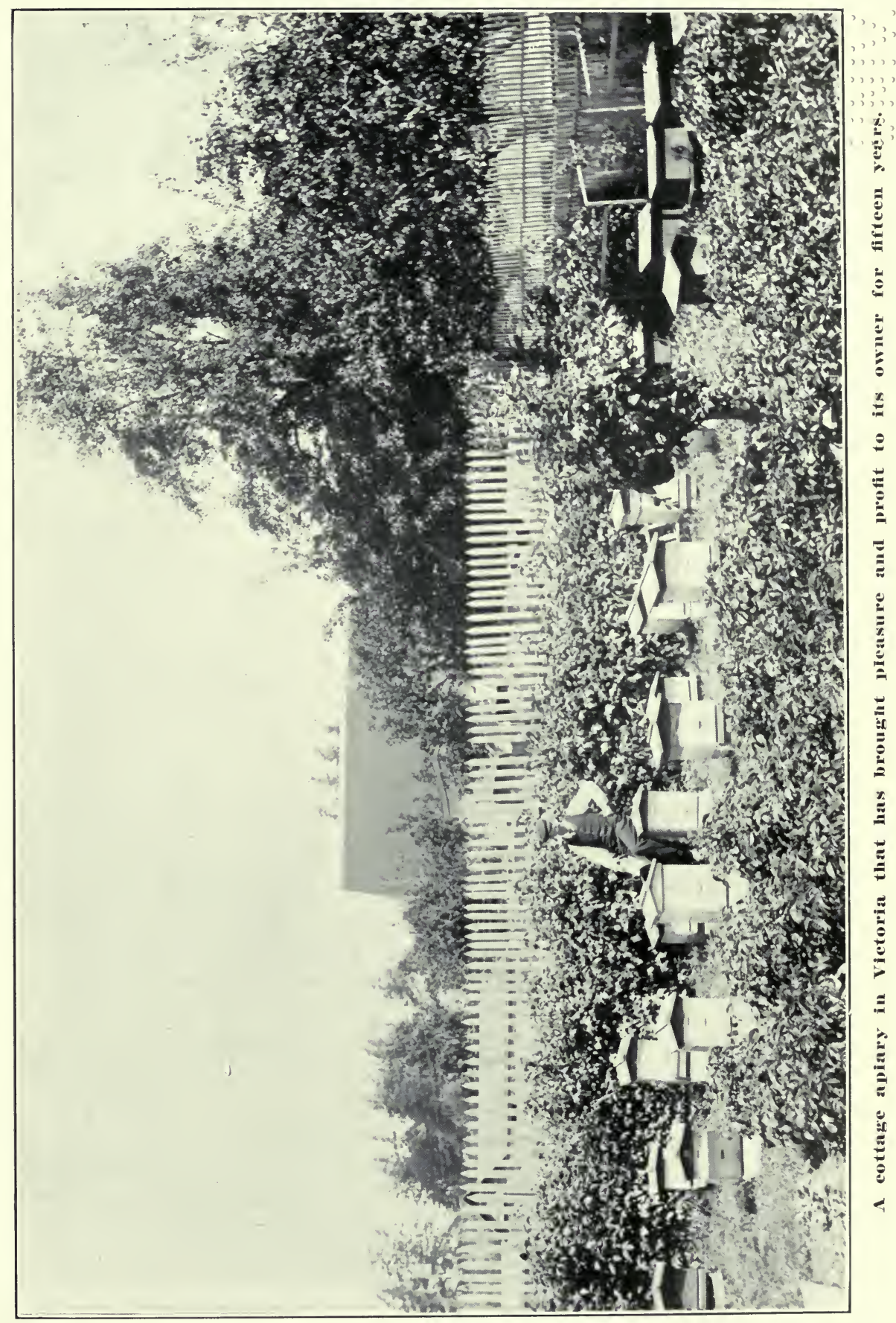


Digitized by the Internet Archive in 2008 with funding from Microsoft Corporation 
honey-plant that in most regions can be depended upon for a good average yield in a series of year's, and so even experienced bee-keepers are tempted to assume that the presence of clover in quantity should indicate a good honey region. This does not necessarily follow, for both summer and fall droughts or cool summer evenings may retard the seeretion of nectar; yet there may be a good honey-flow in such a region from a very different source. The sourthern end of Vancouver Island would appear to be a good example. Clover is plentiful in many portions, but is sparingly visited by the hees. Some years the snowberry bush is generally covered with blossoms at the time clover is in bloom, and a good supply of very delicious honey is secured. Therefore, any one contemplating an extensive investment in bee-culture should not venture on a very large seale until he knows for a eertainty the actual souree of the honey-flow and how extensively it is to be found within a radius of a mile and a half of the apiary.

\section{White Clover the Chief Source of Nectar.}

In every report that has reached the Department white clover is given the eredit as the main source of surplus honey. One from the south end of Vancouver Island also includes snowberry. Fireweed or willow-herb (Epilobium angustifolium) is reported from New Westminster and Rossland; at the latter place it is s sid to aiways yield well. T'he fruit-blooms of the Okanagan Valley, as will be seen later on, are credited with yielding good returns. Summerland reports sage and Vernon alfalfa as honey sources. Cranbrook is faroured with clover, alfalfa, fireweed, and sweet clover. In West Kintenay generally clover is the only source eredited, but one region ineludes raspberry. In Yale I)istrict alfalfa and wild mustard add to the honey-crop.

\section{Fory is which the Crop is Prodeced.}

As the nights in British Columbia are eool even in summer, it is not a favourable region for the produetion of section honey-that is, honey in the comb-and all the reports confirm this. A comparison of the selling price of the two forms in the grocery stores shows also that extracted honey is the more profitable to produce.

\section{(QUantity of Honey got From kach Hive.}

It is not alone the eharacter of the region that influences the size of the crop; the skill of the bee-keeper plays no unimportant part. It is a truism in bee-keeping that iny one can get a good harvest in a good year, but it requires skill to get a fair crop in a por season. Notwithstanding all this, there is surprising agreement when one groups t'ie data from the different regions. On striking an average from all reports from each locality, the Okanagan Valley is first with an average maximum of 105 sections a hive, nnd an average minimum of 38 . The highest return is 150 , the lowest 24 sections. When run for extracted honey, the average maximum is 141 pounds; the average minimum, 52 pounds. (ireatest yield for a live, 200 pounds; smallest, 30 pounds. Vermon and summerland show the best figures.

Around New Westminster the average yield in section honey is given as 42 ; the highest quoted is 60 ; the lowest is 20 . In the extracted form the average maximum is 8.2 pounds; highest, 200 pounds; lowest, 12 pounds. The avernge minimum is 28 pounds. In several instances attention is drawn to the fnet that the eharacter of the ground in the immediate vieinity is very important, as bottom lands that are sometimes under water usully give the best yields. The region abwe the Delta would appear more favouralle. Puilding up in the spring is slow, on account ef cool weather. One raneher in Chilliwack who hus kept bees for fourteen yeurs says: "We keep bees now only to make certain the pollination of the fruit. Do not advise any one to try to make a living in this region from bees, as they rarely do more than get sutheient stores to winter on, and often not that much. Our nights are too eool for the secretion of nectar." 
In the Kootenays, bee-keeping would appear to be in its infancy. Only one report has been received from East Kootenay, the writer being a resident of Cranbrook. $\mathrm{He}$ has secured as high as 100 pounds of extracted honey a hive in a good season, and altogether seems satisfied with the returns.

In West Kootenay, Revelstoke reports 40 to 56 sections per hive; Proctor a little more; while a Kaslo bee-keeper with ten years' experience gets 50 sections, adding that his source is entirely from the clover in the town, there being no nectar-bearing plants in the vicinity. One apiarist in Revelstoke believes there is sufficient pasturage for 200 colonies in the neighbourhood.

On Vancouver Island, bee-keeping has been carried on for about thirty years, and at present there is an almost continuous chain of hives from Victoria to Comox. The general climatic conditions are rather sinilar throughout the entire line, but the advent of the spring blossoms is much later by a few weeks in Nanaimo than in the south end of the Island. There is, however, great unanimity in the statement of returns, which, briefly put, is 25 sections per hive, or 40 pounds of extracted honey. There is also general agreement that a few hives make an interesting side-line that yields a moderate profit, but there is no present possibility of bee-keeping on an extensive scale with any hope of financial success. The climatic conditions are very similar to those described as existing in the New Westminster region : cool weather in spring, and cool nights in June, this month being the season of the honey-flow.

From the Fraser River, in Yale District, two reports were received. At Lytton the principal source is alfalfa, the yield being 50 pounds extracted a hive. At Agassiz the source is clover and fruit-blossoms, giving 25 pounds surplus in a good season.

Speaking broadly, the dry-belt region of the Province is far ahead of the coast districts for the purposes of bee-keeping.

\section{Seasonat Developments.}

In the southern part of Vancouver Island the bees have occasional flights in January and February, but it is not until about the 20th of the latter month that they fly freely, and by that time the willow is in bloom. so that pollen is often carried in during the last week. Nanaimo reports free flight early in March, but Comox is later by a few weeks. Willow is plentiful in all regions.

From the Delta up to Mission free flight is usual in the first week of March. At Revelstoke it is after the middle of the month. All along the Fraser River willow is reported as plentiful.

In the Okanagan and other dry-belt regions the date of free flight varies from the 1st to the 15th of March. At Vernon the first pollen is carried in about March 12th. However, from several districts of the arid region there comes a complaint of the lack of pollen in the spring, so that it will be probably advisable to provide a substitute in the form of pea-flour, according to the methods described in a later chapter on feeding. In contrast, Rossland reports a plentiful supply of pollen.

In most regions dandelions and fruit-blooms follow the willow; in fact, one rancher wants to know how to get rid of the first named, a rather unusual request from a bee-keeper. The writer would like to oblige with a remedy, but though he wrestled with the problem for several years and consulted many experts, the only conclusion he arrived at was this : the more thoroughly he mowed the lawn, the quicker it developed into a dandelion paradise. Therefore, like a child, he learned to love the glorious display of yellow; as a bee-keeper, he welcomed the blossoms.

Clover and snowberry bloom round about Victoria about June 1st, but it is not until about the 20 th of the month that the bees begin to get surplus honey. As fruitblooms are over about the last week in May, there is frequently quite a dearth of nectar 
for several weeks, but pollen is more than plentiful. It is at this time that many a honey-flow is lost unless sugar syrup is fed to keep up brood-raising in the hives, so that the colonies may be strong when the flow of nectar does start. Similar conditions would seem to obtain along the lower part of the Fraser River. In the irrigated fruit regions there is apparently no break in the flow of nectar, so that brood-raising is continuous after it once starts.

On Vancouver Island the honey-flow is over by the middle of July. Like conditions prevail in the New Westminster District.

In the Okanagan and similar regions it would appear that surplus honey is got from the fruit-blooms. The flow from clover ends with July.

No fall honey-flow is reported excepting from the Okanagan, the source being sage-brush in August and September.

\section{HoNEY-DEW.}

Honey-dew, which is usually considered to be an excretion from aphis and certain scale insects, is in some years very plentiful on Vancouver Island, and is freely gathered by the bees in the absence of nectar. It is considered very poor winter stores unless the bees are fortunate enough to have an occasional flight in December and January. It is very dark in colour, and when mixed with the honey in the supers impairs both its colour and flavour. It occurs also some years along the lower part of the Fraser River, but in the dry belt it is practically unknown. It would appear to be most plentiful in the fir-tree regions.

\section{Fall Feeding.}

It is generally necessary to feed sugar syrup in autumn on the south part of Vancouver Island, but from Nanaimo to Comox feeding is generally unnecessary, and the same is true of all points on the Mainland.

\section{WINTERING.}

The general custom appears to be to winter the hives on the summer stands all over the Province. On Vancouver Island and the lower part of the Fraser River cellar wintering is impossible, as there are occasional warm days throughout the winter when hees fly freely. Many bee-keepers in these regions make no difference between summer and winter coverings, but others endeavour to keep the hives dry by wrapping with tar-paper or by placing in an open-fronted shed. In the dry belt a few favour cellar wintering, but the majority consider the average cellar as too damp, and so pack the hives with shavings, leaves, or similar material held in position by a water-tight casing, such as a box. Those with double-walled hives make no special preparations at all.

\section{Hive Preferred.}

The Langstroth hive is practically the only one in use. There is equal favour shown between the eight-frame and ten-frame hive; in fact, where both sizes are tried, any comment is to the effect that there is practically no difference in the results.

\section{RACES of BeEs.}

A few have blacks, all others Italians. There is a little warmth occasionally shown on this rather interesting and controversial subject. The blacks have their defenders, but many of those who favour the other's want to sec the dark bees wiped out, one enthusiast going so far as to wish the Provincial Parliament to pass an Act ordering the decapitation of every black queen within its jurisdiction, in order to keep the Italian stock pure. Hybrids seemingly have no friends, on aceount of their vicious disposition. 


\section{Market Prices of Honey.}

No attempt was made to get quotations of the market prices of honey, but one may safely presume that those ruling in Victoria and Vancouver are at least indicative of the rest of the Province. Here, as elsewhere, the stores prefer a package of such bulk that the price charged will be represented by a coin such as $25 \mathrm{c}$., $\$ 1$, or even two coins in the higher values. Such prices as 20c., 65̃c., and $\$ 1.15$ are not popular, either with the trade or the customers. On the other hand, one must of necessity pack the honey in some vessel that is a stiple commodity on the market; so it calls for quite a little consideration on the part of the producer to harmonize as far as possible the conditions. In Victoria we find the containers in common use are half-pint, quart, and two-quart fruit-jars, United States measures. When filled with water, the contents weigh respectively $\frac{1}{2} \mathrm{tb}$., $1 \mathrm{lb}$., and $2 \mathrm{lbs}$. But honcy is nearly one-half heavier than an equal quantity of water ; therefore, the jars will hold almost $\frac{3}{4} \mathrm{tb} ., 1 \frac{1}{2} \mathrm{ths}$., and $3 \mathrm{Hts}$. of the product of the hive. Larger quantities are sold in tins, the usual sizes being $5 \mathrm{fbs}$. and 10 tbs.

The retail prices for the three snialler sizes are 25c., $85 \mathrm{c}$. , and $\$ 1.50$. The grocer usually pays for thein $20 \mathrm{c} ., 67 \mathrm{c}$., and $\$ 1.22$; that is to say, he gets a discount of 20 per' cent. on the retil price. Probably two-thirds of the sales will be of the $25 \mathrm{c}$. size.

The half-pint jars in gross lots cost 5.2c. each; the quarts in dozen lots cost 12.5c.; the two-quart jars in dozen lots cost $17 \mathrm{c}$. A little figuring will show that when the bee-keeper sells to the grocer he will get at the rate of $19.7 \mathrm{c}$. a pound for the honey in the smallest jar, 18.5c. for that in the quart jar, and 17c. in the two-quart jar. When the apiarist is located near a city he will generally have no difficulty in selling all his product direct to the consumer at the full retail price, thus getting 5c. a pound more.

Comb honey usually retails at 25c. a section; price to the grocer, 20c. The average section contains 14 ounces of honey, so the bee-keeper is getting at the rate of almost 23c. a pound. This looks better returns than is got from extranted honey, but we must deduct cost of section and foundation starter, and then the two will come rather close together. Then when we consider that it is generally estiniated that a colony of bees will produce in comb honey only two-thirds what it will yield in extracted, we see at once that in British Columbia extracted honey is the more profitable form of honey production. We have already learned that on account of the cool nights the bees make a rather poor showing when working for comb honey.

From Dominion statistics we learn that during the year 1909 there was imported through the ports of Vancouver and Victoria a grand total of $81,431 \mathrm{lbs}$. of honey. These figures indicate a demand in the Province it will take a long time for the beekeepers to supply. When we remember that there is a protective tariff of 3c. a pound on honey from foreign countries, and that freight rates from most points of large production are almost 2c. a pound, we readily see that there is little likelihood of a sag in prices of this most delectable of ranch products.

\section{Bees and Fruit-raising.}

Not so very many years ago it was no uncommon thing for a farmer to believe that the honey-bee stole a valuable essence from the clover and fruit blossoms, but now he knows that without bees his crop of seed and fruit would probably be scant. Crosspollination of most fruits is the work of insects, it being estimated that sixty-eight different kinds visit apple-blossoms alone. But the problem is to get a sufficient number when there are hundreds of thousands of blossoms all open at one time as in a bearing orchard or strawberry-field. The honey-bee is the only insect under human control, so by keeping a sufficient number of hives we can generally have enough bees on hand when they are most needed. Further, experience shows it is essential to 
scatter the hives throughruut the territory to be worker. In 1910 , in the Wenatchee Valley, Wush., a careful investigation showed that on apple-trees not over 100 yards from bee-hives only 7 per cent. of the fruit-spurs failed to set, while of those farther away 49 per cent. failed. The professor in charge of the investigation says : "Our conclusion is that, in order to prevent crop failure from lack of pollination in the future, we must get bees. The common honey-bees are the best insect pollinators on earth. They come out earlier in the spring, stay out later in the fall, begin earlier in the morning, and work later in the evening, and they will work under more unfavourahle conclitions than any other insect. From my work with bees 1 have caleulated that a single honey-bee is capable of cross-pollinating over 16,000 apple-blossonis in a day (this nay be a misprint, but the number visited is certainly large); but during the blossoming period there are so many blossums that the bees do not go far from the hives, so we nerd hives all over the orchard."

Another authority says he considers that in every orchard there should be at least one colony of bees for every twenty-five trees, in order to secure thorough pollination of the fruit-blossoms.

\section{Partial List of Honey and Pollex Plants in British Colunbia,}

When Dr. Watts, the eminent hymn-writer, said of bees that they

Gather honey all the day

From every opening flower.

His statement was not altogether in arcordance with fact, for they patronise but a small proportion of flowering plants. For weeks at a time bees need very little attention ; on the other hand, there are occasions when they need care at once, and these are usually dependent on the floral conditions; hence it is very important that every hee-keeper should be familiar with all the bee-plants of his locality. He should know the dates of blooming, and above all what time in the spring there is a likelihood of a dearth of neetar, so that, if necessary, he can tide over the period by feeding with sugar. The writer alvises the keeping of a diary, which in his own case is a rather simple affair, consisting of a sheet of paper $8 \times 10$ inches in size, on which he records the first appearance of the blossom of each variety of plant, occasionally adding a little note for guilance in future years.

The list given below contains all plants in the reports; the dates show when they bloom in Victoria. The remarks arise out of the writer's experience in the same city. Doubtless the list can be considerably extended, and so every bee-keeper is invited to send additions to the Secretary of the Department of Agriculture, so that they may be adderl in future editions :--

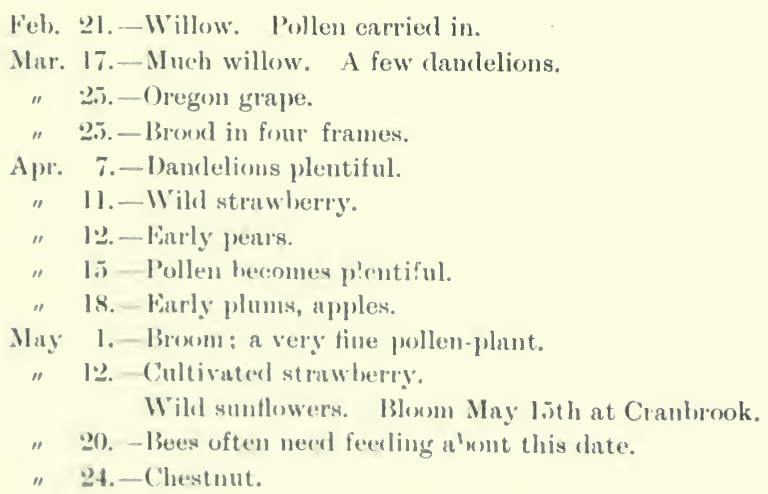


May 24.-Vetch. Bees work on stems.

" 28. - White clover and hawthorn.

June 7.-Snowberry, chokeberry, mustard, stonecrop.

" 22. - Bees rushing on snowberry. Goldenrod, buckwheat, fireweed, sage, sweet clover, and alfalfa are reported from various parts of the Province, but dates of blooming are not given.

\section{CHAPTER II.}

\section{Starting Bee-keeping.}

To learn the art of bee-keeping, one must keep bees. It is not enough to buy a colony and trust to luck for the outcome; the owner must learn to keep bees, that is to sily, have them at the end of some definite period, say twelve months or five years, or longer. The beginner in bee-keeping must realise that bees are just a variety of stock, like cattle, hogs, or chickens, and, like them, must be taken care of ; therefore, he must learn about bee needs and bee habits, so that in times of necessity he can give the little aid that is required to tille them over the period of trouble. Too many beginners assume that bees need no care, that they will work for nothing and board themselves, yielding profit in the form of honey, and multiplying their kind several times in the course of a single season, so that by the investment of a few dollars in one hive there will in a very few years result a good-sized apiary that has easily paid its way out of surplus honey.

The actual facts do not correspond with so rosy a picture. Without doubt, bees will pay better returns for the capital, time, and labour invested than any form of farm enterprise; but the big returns are got, one year with another, as the result of knowledge and skill judiciously applied. It is undoubtedly true that in most years bees reproduce themselves prolificly by means of swarms; but this is Nature's way of compensating for a high death-rate in normal conditions, so that there will generally be in an average of years just about the same number of colonies in a certain locality. Any permanent increase must be brought about by the skill of the bee-keeper.

Again, the production of surplus honey is not the reason for the existence of the colony ; this result is due to the manipulations of the apiarist. In a state of nature, what would be surplus honey is transformed into more bees, until the hive is overflowing when it divides, often several times, into duplicates of itself. Bees, we thus see, make honey, and then out of the honey make more bees. So the colony that sends off swarms is not always a honey-producer that season; hence the bee-keeper who is working for surplus honey is generally endeavouring to find a sure method for the prevention of swarming

The purpose of this book is to set the beginner in bee-keeping in British Columbia on the right track, but he is advised to see, if possible, an experienced apiarist open and examine a hive, if for no other reason than to gain confidence in himself, so that he may do slowly and methodically what he is tempted to rush rather hastily.

\section{How to start Bee-keeping.}

In most regions the best time to begin bee-keeping is in the end of April or the beginning of May. Not only is it near the commencement of the honey-flow, which in this Province is mostly from white clover in June, but the risk of loss through the death of the colony is at the minimum. Of course, the novice is ignorant of what constitutes a good colony; but if he buys a hive in which the bees are clustering in six 
spaces between frames on May lst, he will get one in first-elass condition. He should buy only one hive, for he will learn as much in the first year from one colony as from twenty, while if he lets them run themselves his financial loss will be at a minimum. The nian who cannot take eare of one colony and its increase in one season is lucky to learn his inability at small cust. After the first season, only such money as the bees have actually earned should be invested in increase. A little experience will soon show that every colony on the stand at the beginning of winter will represent an actual eash ontlay from $\$ 8$ to $\$ 10$.

The novice should not be tempted to buy a colony housed in a soap-box or similar makeshift; in fact, such a combination means endless annoyance to any one not an expert; but he should see that he gets a modern hive in good physical condition, free from eracks and loose joints.

\section{The Hive to choose.}

There have been fashions in hives, but the bee-keepers in British Columbia are almost unanimous in preferring what is known as the Langstroth hive, with eight frames. There are other hives in use; a few men on the Mainland use the British standard, while on Vaneouver Island there still linger examples of the Gallup hive, which is about 14 inches square and deep. There are also in use a few hives about half an inch longer than the regular Langstroth. Modern bee-keeping demands that al frames be interchangeable, hence the beginner will be wise to start with a standard size and so avoid future annoyance. A factory-made eight-frame Langstroth hive is usually of $\frac{7}{8}$-inch lumber, and is 20 inches long, $13 \frac{7}{8}$ inches wide, and $9 \frac{1}{2}$ inehes deep, outside measurements. If home-made, it will probably be of $\frac{3}{4}$-inch lumber; hence the length and width will be a quarter of an inch less than the sizes given above. It is, however, the inside dimensions that count. These are : Length, $18 \frac{1}{4}$ inches; width, $12 \frac{1}{8}$ inches ; depth, $9 \frac{1}{2}$ inches.

When possible, it is wisdom to have the bargain include the delivery of the hive and placing it in position, as this foresight will in all likelihood evade many stings, and insure the colony being placed in a suitable location-that is, one sheltered from cold winds.

\section{Cost of First Season.}

The cost of a venture in bee-keeping should not be much over \$20, made up thus :-

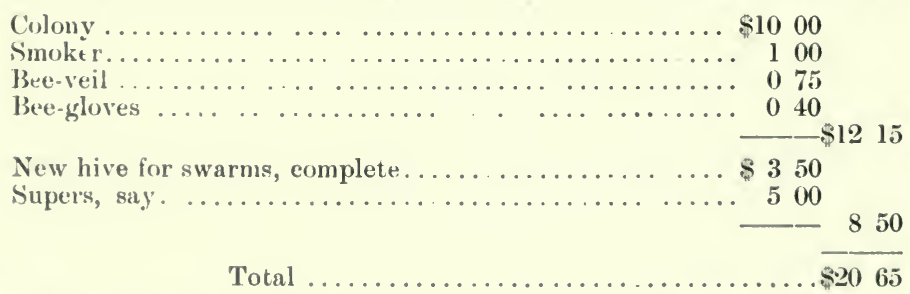

The ahove prices are not the lowest possible, but a fair average. If uneontrolled swarming be permitted, more new hives may have to be bought, running up the total cost to not more than $\$ 30$.

\section{Locatiox,}

The location of the bees in the yard is important. The hive should be sheltered from eold winds in the spring months; hence, in most regions it should be shielded on the north by a fence, clump of shrubs, house, or barn. On the other hand, in the summer month there must be free circulation of air all round; therefore, the hive must be at leust 6 feet from the fence or building. The position of the entrance is not really important, but it generally faces the sonth, so that the sun's rays in spring will send 
warm air into it, while as the end of the hive warms up the heat will circulate between the frames. When the doorway faces east or west the noonday sun heats up a side, warming up a comb next to it, but not affecting in any way the middle frames, on which the bees are apt to be clustered.

The hive must not rest on the ground, as the moisture will rot the bottom board. So far as utility is concerned, a couple of pieces of rough 2 by 4 lumber are as good as anything. If the ground is uneven, it must be marle perfectly level, for perfect combs cannot be secured if the frames are off the plumb. During the rainy season the back end of the hives should be raised an inch or two, so that water may run freely off the alighting-board.

\section{CHAPTER III.}

\section{Tools and Dress.}

The tools essential for the practice of bee-keeping in a small way are neither numerous nor expensive, consisting practically of a smoker and a hive-tool. The latter may be disposed of in a few sentences, so will be dealt with at once. Its principal use is to force apart the frames, which are generally glued together by an adhesive known as propolis. As any piece of flat and light metal is fit for this simple work, we find the majority of bee-keepers are content to use a screwdriver or a wood-chisel an inch wide in their ordinary work. But once in a while one must scrape away the accumulations of wax and propolis from the frames, or the deposit of dead bees and other waste matter from the bottom boards, so that a tool with a scraping-edge is a great convenience. Many hive-tools have been invented, but after trying about a dozen the writer pins his faith to the Root tool, which is illustrated in Fig. 1. The bent end is used for scraping, the straight one for separating frames and hive bodies.

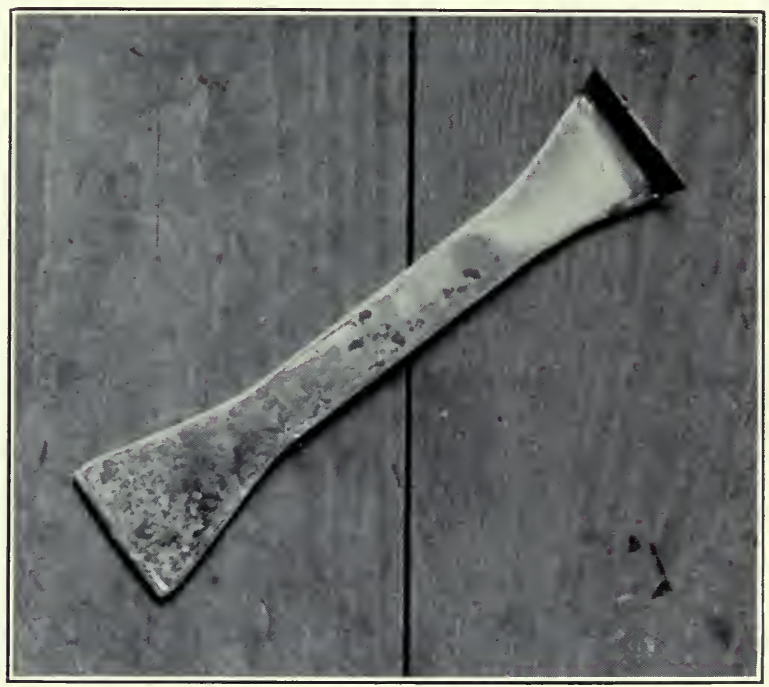

Fig. 1. Root Hive-tool. 
THE SMOKER.

Bees have an instinctive dread of smoke, probably due to the fact that their natural home is in the hollow trunk of some forest tree, where the greatest danger that can threaten is fire. Safety lies in flight, and so when fire threatens the bees gorge themselves with honey and endeavour to reach some region outside of the danger zone. This we know, that if we drive smoke into a hive the innates proceed to lap up the honey in the cells and ignore the bec-keeper when he proceeds to break up their home by removing the frames.

The smoker of to-day consists essentially of two parts, the bellows and the stove. Figs. 2 and $2 \mathrm{~A}$ illustrate types on the market. In the first the grate is below the fuel, in the second it is above. The latter works nicely for a while, but soon the grate becomes elogged and the smoker is out of business. The writer, therefore, recommends the one with the grate below the fuel, which is shown in Fig. 2.

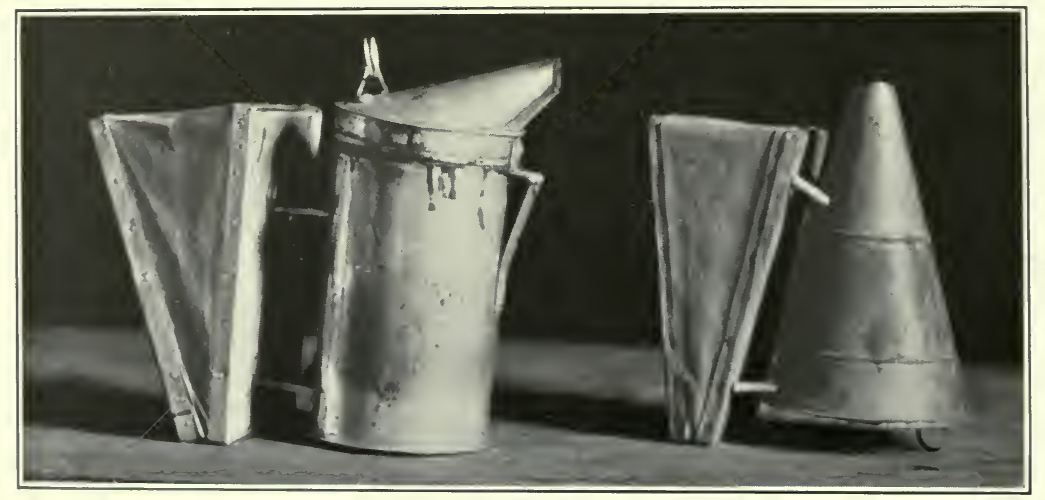

Fig. :-

Smokers.

Fig. 2 A.

The stove is fed with any substance that will burn slowly and give off pungent smoke. Cotton or linen rags-never woollen-are very good, so are pieces of old sacking, especially if weather-worn. The writer has found an old tent, so rotten that it tore easily, a very suitable form of fuel. Greasy cotton-waste is excellent, and can usually be had for the asking at any factory or printing plant. Many bee-keepers use the prumings from fruit-trees once they are thoroughly dry, but as they give off a great deal of a tarry substance the writer does not recommend their use.

'The smoker is started by placing a small piece of burning rag on the grate at the bottom, then this is fanned into flame by working the bellows gen:ly. At intervals more is added, until the stove is too hot to tomeh, and then the full loading is done. A gonl smoker should keep alive for several hours without attention, when not in aetual use, and he rendy for husiness after a few puffs with the bellows. When in steady demand it should always be stood on end, so that a slow draft is passing through the stove all the time; if not wanted for some time, it should be laid on its side so as to secure very slow combustion.

I) RESS.

The sweet stores of the honcy-bee are exceedingly tempting to many forms of animal life; therefore Nature provides her with a very efficient weapon of defence, not offence, in the shape of a sting, so whover desires to rob the hive of its toothsome treasures must be protected against the littlo javelins. Ordinary clothing is a sufficient 
covering, so far as it goes, but in addition the head must be shielded, while with most people the hands are all the better of being protected. Many experts rarely use gloves, having attained a stage at which a sting gives little annoyance; but, as a matter of fact, the writer finds that much of the poor bee-keeping he has come across is largely due to the dread of stings. When a man has to lay off work for a couple of days

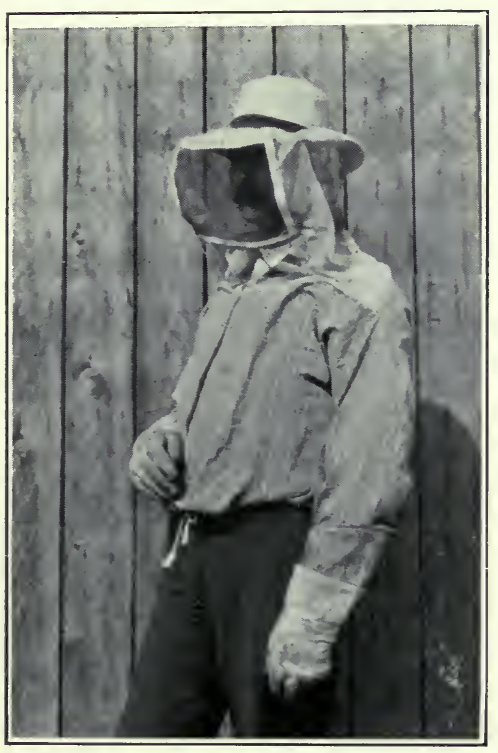

Fig. ?.

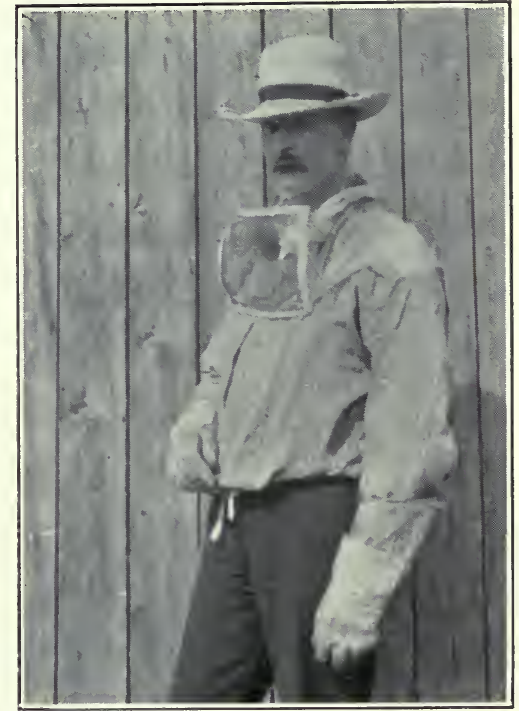

Fig. 4

because of a sting in his wrist, and at the same time does not know how to get perfect protection, he can scarcely be blamed for leaving his bees alone as much as possible, even if neglect means the loss of half the crop. The beginner will, therefore, be wire if he provides himself at the very ontset with a really sting-proof costume. Such a one is shown in Fig. 3, and is the invention of one of the biggest bee-keepers on this continent.

Essentially the dress consists of a blouse, to which is attached an upper part of white $n$ tting, this being faced with a square of black mosquito wire ganze. The simplest way to make this su.t is to buy a cotton nightshirt two or three sizes larger than is ordinarily worn, cut off a part above the shoulders and another below the waist. From the latter portion make extensions of the sleeves so that they will reach down a little below the knuckles, then cut a hole in the side for the thumb. The lower part of the blouse is taken up with a string hemmed in the edge, so that the blouse can be tied round the wearer's waist.

The black wire netting in front of the face is about 8 inches square, pref-rence, being given to a mesh of eight wires to the inch as permitting clearer vision. To prevent the wire from cutting, the white netting, it is edged with strips of oil-cloth 1 inch wide. These are doubled over the edges, then sewn very slowly on a sewingmachine.

Netting such as is used for window-curtains is the best material for the upper part of the suit, as it permits of the free circulation of air round the neck and head. It should be quite loose at the back, but not in front, for the closer the wire netting is to the face the better one sees. The upper edge of the wire should reach the brim of the 
hat, for if it does not the sun's rays will strike the white netting and irritate the eyes. The black netting is sewn into place with the sewing-machine run slowly, before the white netting in front of it is cut away. The upper edge of the cloth netting has, of course, a piece of elastic hemmed in so that it can be fastened to the broad-brimmed straw hat.

The extensiun pieces that protect the hands are made sting-proof by being coated with a thin layer of paraffin-wax, such as is used for covering home-made preserves which is casily applied while hot by means of a teaspoon.

Fig. 3 shows the suit in use; Fig. 4, how the face protection can be lowered, so that the wearer can take a drink or mop his brow.

\section{Groves.}

With this suit a pair of gloves can be slipped on when wanted. In some regions there are on the market thin gloves of sheepskin that have a glossy surface which is a safe protection from stings. When these are not available one must buy what is on the market, preference being given to a pair with glossy surface, but, of course, any glove may be made sting-proof by coating with paraffin-wax or the least possible quantity of linseed-oil.

\section{BEE-VEIL.}

Most bee-keepers use the ordinary veil, extending from the hat to the shoulders. This style ean be bought in any store that earries bee supplies. It is very tender, easily torn, and not to be recommended where one has to work under low-branched trees. The lower edge in front should be drawn down tight and fastened to vest or a

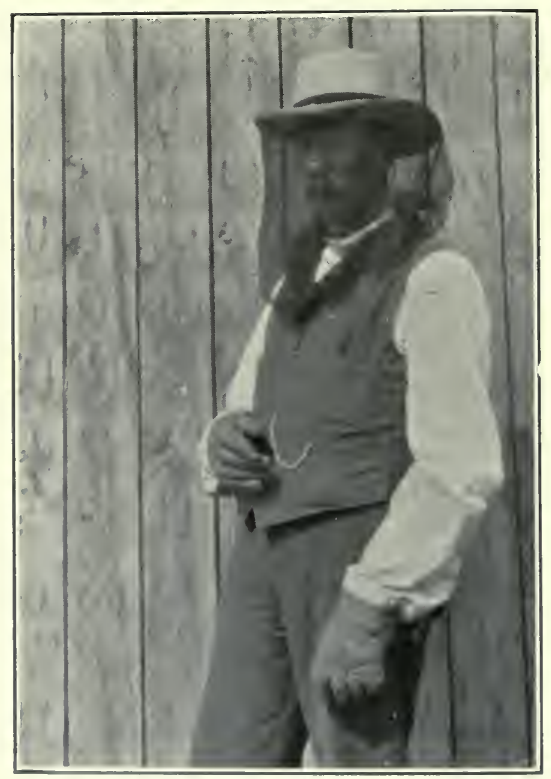

Fig. 5. IBee Vell.

suspender with a safety-pin. When this veil is worn the gloves used must be longsleeved, so as to protect the wrists. These are shown in Fig. 6. They are generally too thin to ward off stings, but a very thin conting of linseed-oil will make them stingproof, though rather stifl: 
The lower openings of the trousers must be closed either by bicycle-clips, pieces of string, or by tucking them into the socks. Boots are, of course, preferable to shoes.

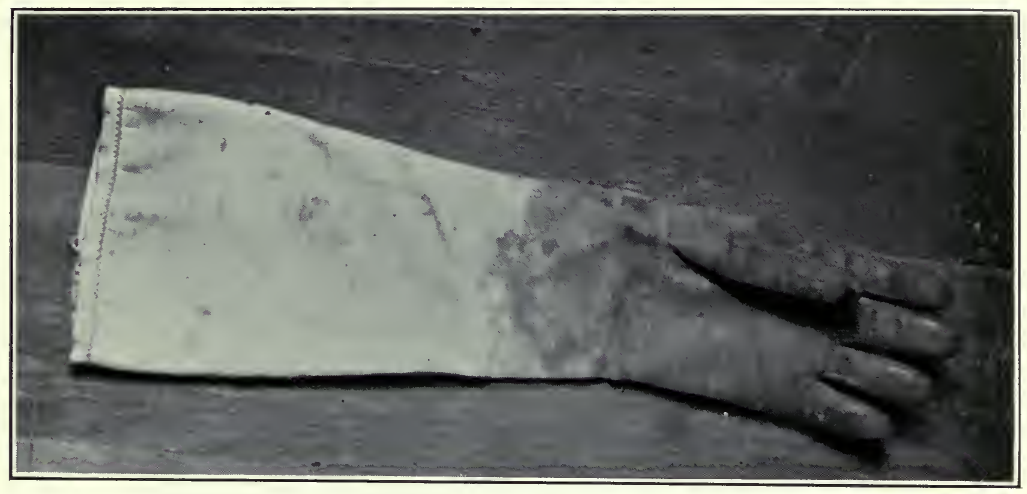

Fig. 6. Bee Glove.

Ladies' Costume.

Ladies should wear either a divided skirt fitting tightly to the ankles, or trousers under an ordinary short dress.

\section{CHAPTER IV.}

\section{Hives.}

The beginner in bee-keeping ought at once to get aquainted with the parts of a hive, also the principles that are involved in its construction. On seeing one for the first time, he might be tempted to assume that the structure in which the bees are housed is a solid piece of carpentry, but examination will show it consists of at least a dozen movable pieces, and even this number is increased in the active months of the year-June, July, and August.

Let us suppose that the reader and the writer are going to examine a hive together, and that the latter is going to explain things a little as the inspection proceeds. We will, therefore, start with a modern hive on the stand, and since we are not side by side in reality, the writer will bring photography into play, and, as far as possible, illustrate each feature that is deemed worthy of notice.

First, we get the smoker agoing, then put on our bee suits. All being ready, we stand alongside the hive, which will appear as in Fig. 7-that is, if it is an eight-frame Langstroth. Looking at it even casually, we observe that like a dwelling-house it has a roof, side-walls, and a foundation. These three are definite and distinct parts; furthermore, they are essential features of every modern hive. If you take hold of the roof you will find it to be removable, sometimes with a little difficulty, as the bees have a habit of fastening it down tight to the walls with propolis, so as to prevent the escape of heat from the interior. Just keep this little fact in mind, for as we proceed with our investigations we will learn the reasons for the bees' desire to keep warm the inside of their home. Fig. 8 shows the hive-cover removed. So far we have not seen the inside of the hive, because on lifting the cover we find a cloth quilt just underneath. 
This may be made of any kind of fabric that will retain heat, but ordinary table oil-cloth is generally preferred, with the glossy side turned down, because the bees will attack fibres of ordinary cloth and carry them outside. It is, however, a good plan to put a piece of ordinary cloth, such as a double layer of sacking, above the oil-cloth quilt.

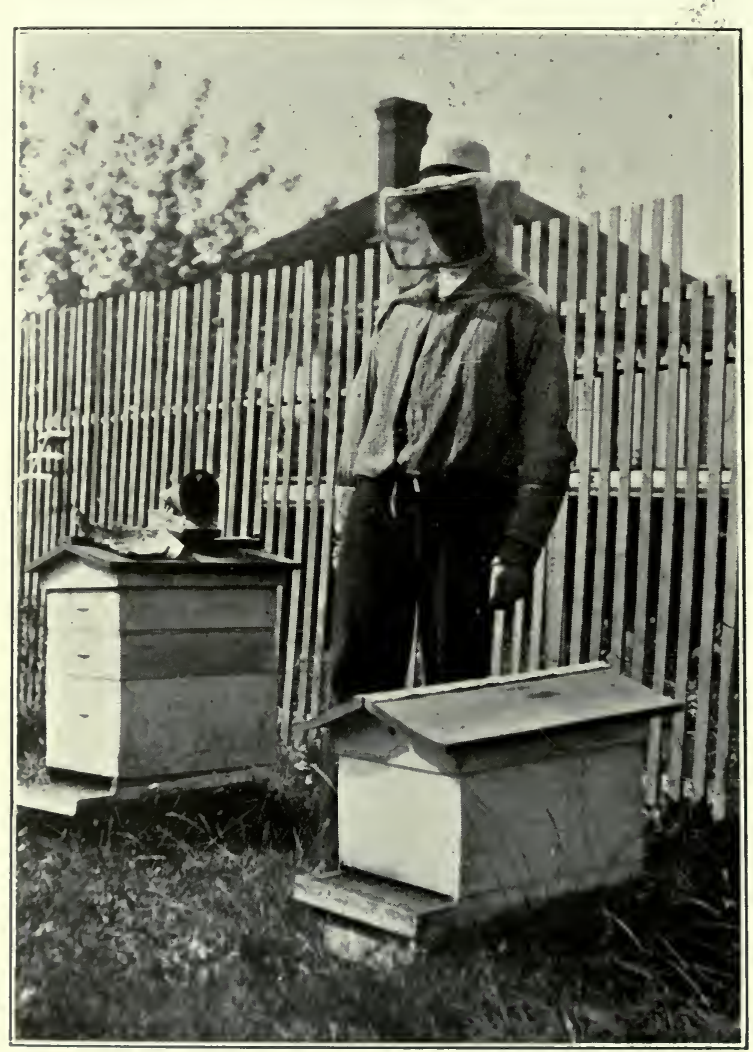

Fig. 7 .

8-Frame Hive.

Our next step is to remove the quilt. The interior of the hive is now presented to our gaze; at least, we see the tops of the frames from between which, if it be in late spring or summer, thousands of bees are appearing and covering the upper part. Fig. 9 shows the frames.

We will now have a chance to learn something about the temper of the insects in this particular hive, for if they are good they will not offer to fly, but if they are bad they will run round and fly off, some at us, some at the hive entrance. Now is the time to use smoke to keep them in subjection; how much will depend upon circumstances, but never any more than is necessary. In the case of a colony known to be irritable, it is usually necessary to give a puff or two into the hive entrance before removing the cover, but with gentle bees a few puffs across the frames, never down throngh them, will be suflicient. In spring and autumn when the colonies are weak in numbers it is of ten unnecessary to use smoke.

Before touching anything we will examine the arrangements a little. The frames are eight in number, jammed tightly together and against one side of the hive. If we 
measure them we will find that they are spaced $1 \frac{3}{8}$ inches from centre to centre, and since there are eight of them, they will occupy exactly 11 inches, thus leaving a clear space of $1 \frac{1}{8}$ inches on one side of the hive. Part of this is filled by a piece of plain board about half an inch thick, with a top bar like a frame, and is known as a follower, though occasionally it is called a division-board. In use it is pushed tight against the last frame. We are now ready to proceed with the examination of the internal arrangements of the hive, and while doing so we will adhere to a few simple rules.

First-We will never stand in front of the hive, for there is the bees' roadway, and they will resent our presence, even to the point of stinging.

Second-We will never put any frame or other part of a hive in front, for the same reason.

Third-We will not have more than one frame at rest outside of the hive at one time, but this rule will not forbid us having another one in our hands.

Fourth-We will take care that we leave all frames in the same order that we found them and turned the same way.

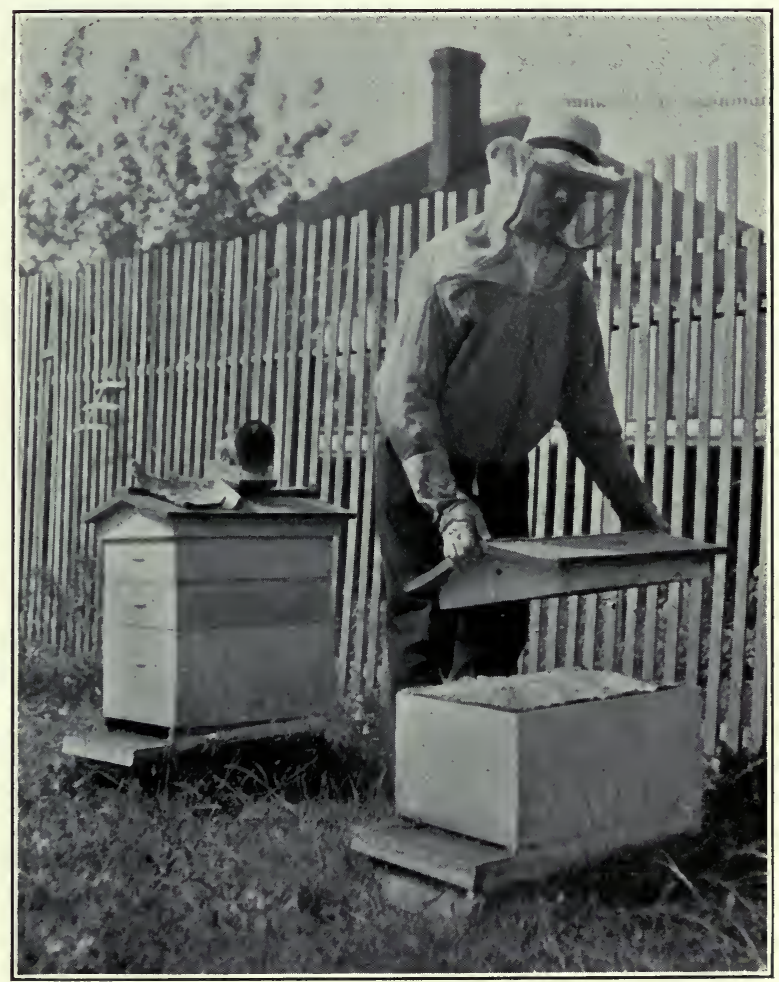

Fig. 8.

Showing Quilt.

Fifth-We will be very slow in all our movements, never dropping a frame into position, but placing it exactly where it belongs, because bees are very nervous creatures and the slightest jar will cause them to fly off the frames and show fight.

Sixth-We will avoid killing a single bee, not only for humane reasons, but because in a bee-hive an injury to one is an injury to all, therefore the death must be avenged. 
Our first work is to remove the follower that occupies the spaee between the frames and the side of the hive. Very probably it will be glued to the frames with propolis, so we insert the hive-tool between frame and follower, pushing aside the bees gently if in the way, then with easy pressure we pry the board apart from the frame, first at one end and then at the other. The follower is now removed from the hive and set to one side, or at the end of the hive. We can now reach the first frame, which is apt to be clear of bees, excepting from May to September. As before, we break the glue adhesion with the hive-tool, then lift the frame with both hands, one at each end bar. Should bees be clustered where the fingers will grasp the top bar, then gently puff a little smoke on them and they will quickly scurry away. Remember it is such little tricks

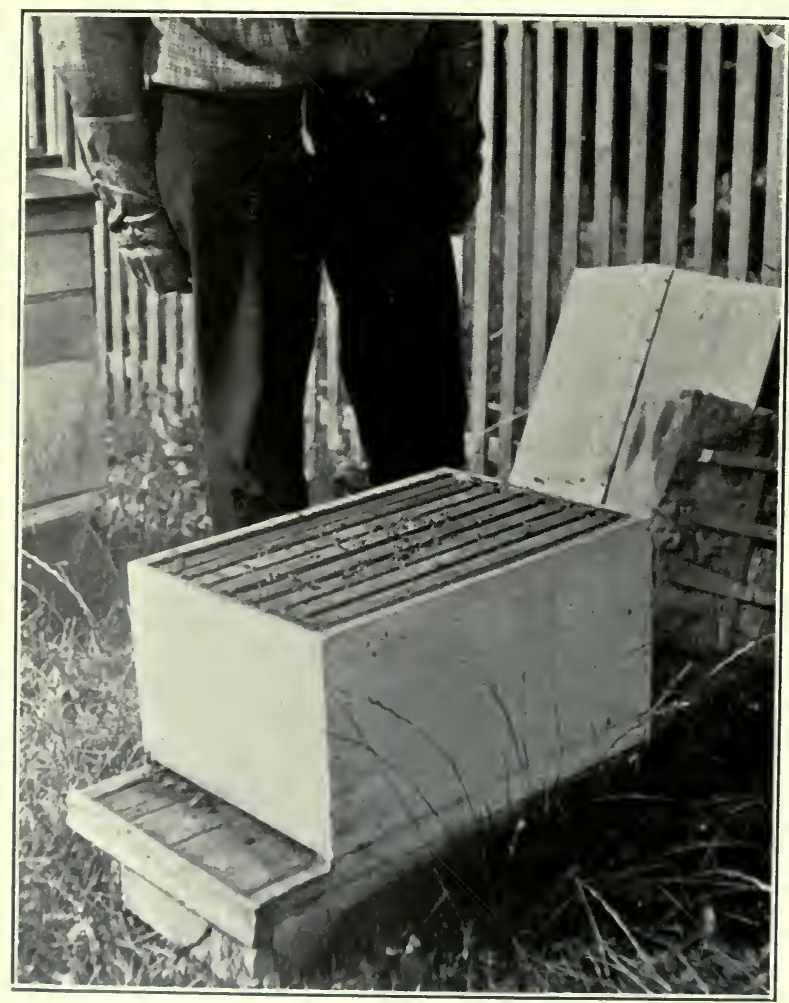

Fig. ?.

Showing Frames.

as these that make hive manipulation easy and prevent the bees becoming ill-tempered. Lift the frame straight up, with your back to the sun, and proceed to examine it. Fig 10 shows the operatiot.

The frame we find is male of four pieces of wood, known as top bar, bottom bar, and end bars. The first is 18 inches long, the second is 175 inches, while the other two will be about 8 inches, depending on the thickness of the top bar. The full depth of the frame is $9 \frac{1}{2}$ inches. The projecting ends of the top bar rest upon rabbets cut into the end pieces of the hive. The frame proper, it should be specially noterl, is inch shorter than the inside length of the hive body, so that between the ends of the frame and the hive there is a space of a little over 1 ineh. 
Modern bee-keeping is based on this vacancy, for until the Rev. L. L. Langstroth discovered that the bees will fill up a space less than $\frac{1}{4}$ inch wide with propolis, and build comb in one largel than $\frac{3}{8}$ inch, a movable frame was impossible. A bee-space then is one that is not less than $\frac{1}{4}$ inch, nor more than $\frac{3}{8}$ inch. It is important that this fact be remembered, for it has much to do with practical beekeeping, and is the reason why it is better for the bee-keeper to buy factory-made goods than to attempt makeshifts of his own construction.

The inside of our frame is filled with wax comb, which is nade up of an innumerable number of cells, at least 3,000 on each side. In these cells is stored the food

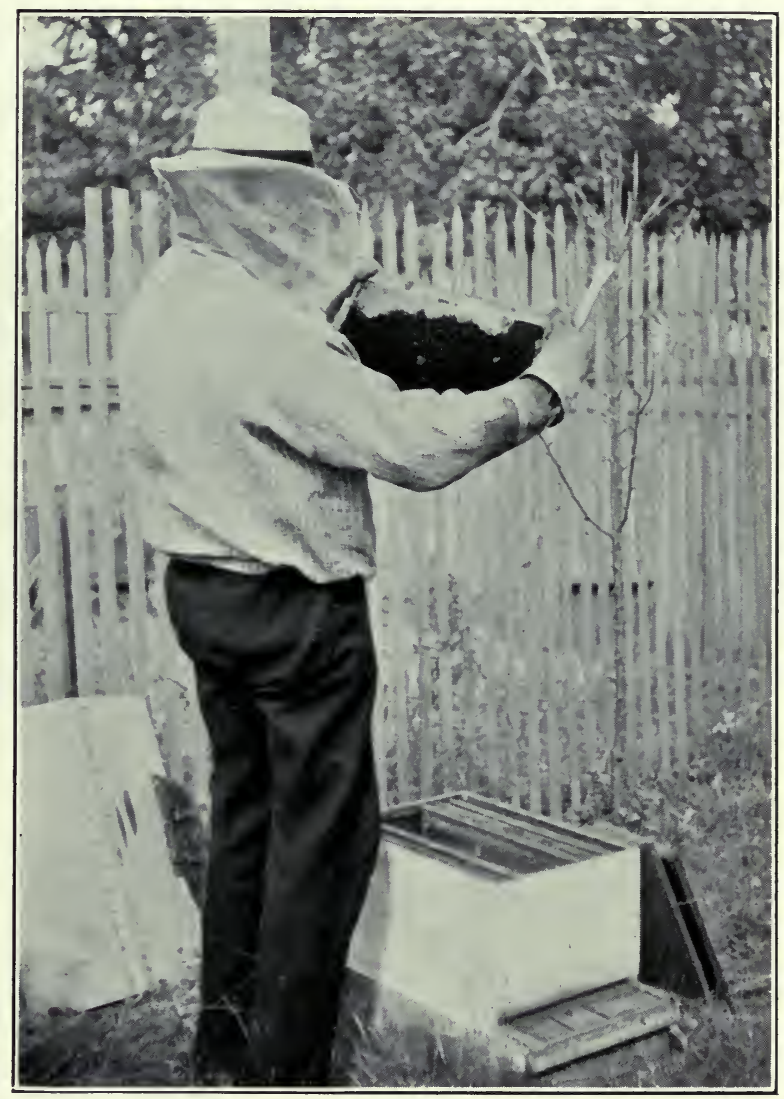

Fig. 10.

Examining a Frame.

supply of the colony ; in them are laid the eggs from which develop the young bees, the whole time from infancy to maturity being spent in such narrow confines. Then in the cold days of winter, when all activity in the hive practically ceases, when the individual members huddle close together to keep each other warm, each empty cell may be filled with an insect so that no space shall be unoccupied. The interior of a bee-hive is a wonderful utilisation of a limited area, down to the minutest detail, and it is hard for most people to realise that in a capacity of about 2 cubic feet as many as 50,000 bees will carry on all the activities of their life, for here is at once a pantry, kitchen, incubator, nursery, living-roon and bedroom for them all. 
But let us investigate our comb a little more, and first we will probably notice that there are at least two different sizes of eells, one series in the upper part of the frame, running about five to the inch; another kind, generally in the lower half of the comb, that are a little larger, running about four to the inch. In the smaller cells the workerbees are raised; in the larger the drones, who are the males, spend their days of infancy. Both kinds of cells are used when necessary as storehouses for food. In a well-managed hive the worker-cells vastly predominate; in fact, all good bee-keepers strive to keep the drone-cells to the lowest possible number. Drones are essential to the welfare of the apiary, but an unlimited quantity of them means a waste of valuable space and food, for they are consumers only. Fig. 11 shows the two kinds of cells side by side.

We will now proceed to examine the next frame, but first we will dispose of this one by setting it on the ground, leaning it against the side of the hive. As before, we will break the gluing between the frames. Since it is May it is probable the colony is strong enough to cover six frames, so that this one may have thousands of bees on

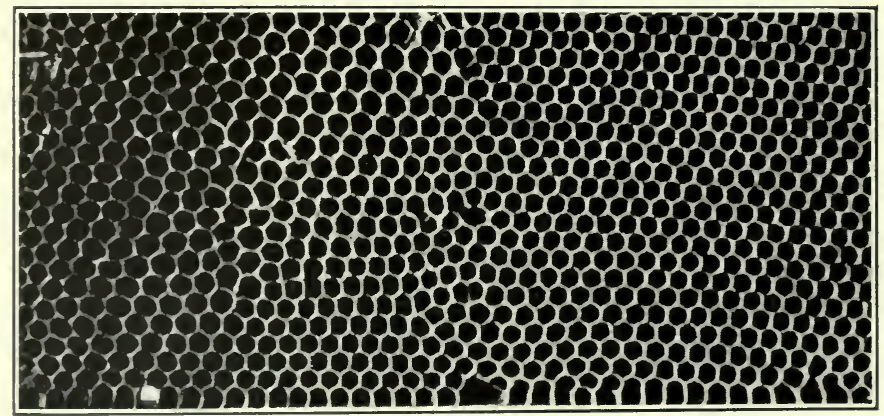

Drone Cells.

Fig. 11.

Worker Cells.

both sides, while the weight suggests that the cells contain something. They do, for the centre of the comb is filled with young bees in all stages-eggs, larve and sealed brood; these surrounded by a band about an inch or two wide of pollen, while outside of that, especially at the top and ends, is honey. Quite a neat arrangement, you see, so as to have everything handy; nursery in the centre with the food all round about. But stop a minute; all the other franses are arranged exactly the same way; so think a little and you will realise that the brood-nest is a ball, with, of course, the most brood in the centre frame, the least at the sides. Now you will understand why you should not disturb the order of the frames when you examine a hive, as changing the arrangement will upset the brood-nest. This is why you are advised never to set more than the first frame outsicle of the hive, just to prevent yourself getting mixed up as to their order. The bee-keeper's business is to help the bees, never to hinder them.

\section{Shaking Bers off the Combs.}

Maybe the eomb is so thickly covered with bees that careful inspection is impossible, in which case hold the frame above the hive, raise it slowly about a foot, then lower it quickly, finishing up with a sudden jerk, when practically every insect will drop on the frames.

Fig. 12 shows the position of the frame at the end of the operation. It is not considered wise to shake the queen off the eombs at the season when she is laying henvily. Another way, which the writer prefers, is to hold the frame perpendicularly 
by the end of the top bar with the left hand, then with the right hand clenched hit the left a smart blow from above (Fig. 13). The comb being free from bees, turn your back to the sun so that its rays shine into the cells. Along the upper part of the frame and at the ends the cells will probably be all sealed, the cappings, as the coverings of the cells are called, being flat, often sunk and wrinkled. Such sealing indicates the presence of honey. On the edge of this region there will likely be a narrow belt of unsealed cells showing the honey, indicating that the bees are using up their stores to feed the young. When we reach the bottom board in our investigations we shall

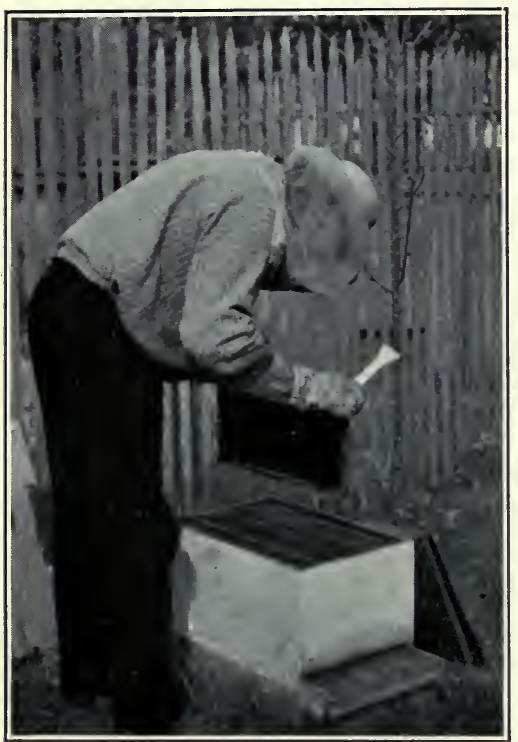

Fig. 12. Shaking Bees off Frame.

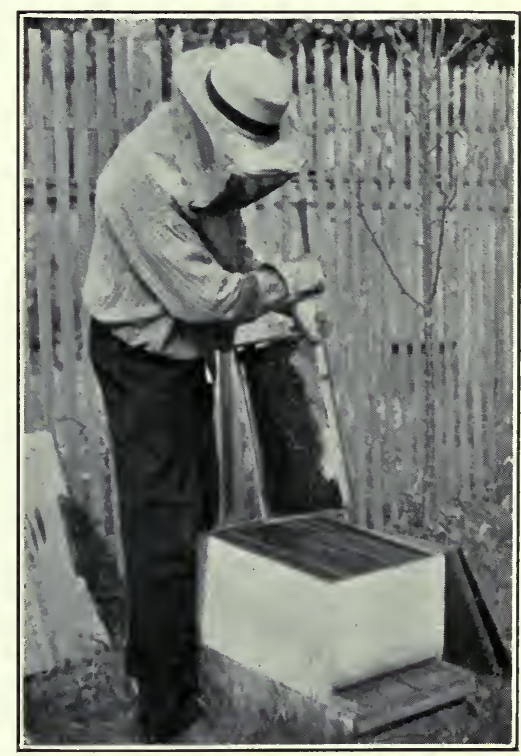

Fig. 13. Knocking Bees off Frame.

find lying there a brownish-looking deposit, like coarse dust, but which is really the fragments of comb-capping torn from the cells.

\section{Pollen Stores.}

Next to the open cells with honey comes a narrow band of cells, filled with a brilliant-coloured solid substance. This is pollen, the bee-bread of our forefathers, which is the male principle of plants, and forms part of the food of the young of the bee while in the larva or maggot stage.

\section{The Brood-Cells.}

In the centre of the frame we find the brood in all stages-egg, larva, and cocoon. The last is sealed over, just as is the honey, with this difference, however, that the cappings are slightly raised in the case of worker-brood, decidedly so with drone-cells. The larvæ or maggots are easily seen, coiled up in the bottom of the cell, especially after they are three days old, but the eggs are harder to distinguish on account of their small size ; in fact, they look like very short bits of white thread attached to the far end-that is, the bottom of the cell. It is just as well for the beginner to learn to detect the presence of eggs in the comb, for an evenly arranged patch is pretty good proof that the queen was busy at least three days ago. 


\section{How to Reverse a Conb.}

A frame has two sides, so you had better look at the other one too. Your most natural impulse will be to cant the frame over, but don't do, for as you tilt it up to the level the weight of the comb is apt to break it away. Try it thus: lower one hand, say the right, until the top bar is perpendicular (Fig. 14); turn the frame half-way round, using the top bar as a pivot (Fig. 15); then raise the hand that was lowered (Fig. 16). Your frame is now upside down with the second side towards you. Here is another method that can be carried out without a pause : Let the lugs of the frame rest on the middle fingers of each hand, these being bent towards the chest. Turn the comb end for end by swinging the left hand to the right of the right hand, then swing the comb up to the position shown in Fig. 16. To get to the original position, reverse the movements.

\section{Replacing Frames.}

When through with this frame, replace it in the hive, pushing it tight against the vacant side. There is no excuse for placing it on the ground. If you have changed it so that you have forgotten which is the front end, just look at the brood, for the bees prefer to have their young towards the entrance of the hive, but the honey at the rear. When you have examined as many frames as you want, push them over to their original position by putting the hive-tool between the side of the hive and the end bar of the frame and using it as a lever. Now insert the frame first taken out, pushing it into place, then the follower. Many bee-keepers insert a wedge between the latter and the wall of the hive, but this is not necessary, excepting when the hive is to be moved in a vehicle of some kind.

\section{The Bottom Board.}

The foundation of the bee-home remains to be examined, and to do this we must lift off the hive-body. Where shall we place it in the meantime? Certainly not on the ground or any other flat surface, as there we might mash bees. A good support is a shallow empty box without a cover, so we place one handy and set our hive across it. Should the bottom board be glued tight to the body, insert the hive-tool between the two at a rear corner, then with a slight twist force them apart.

We now find that the bottom board - so the foundation of this bee-house is called-is of the same width as the hive, but a few inches longer, the projection being in front so as to form a landing-place for the bees. Cleats are nailed to the sides and end, forming a resting-place for the body, at the same time securing a clear run for the bees underneath the frames, thus facilitating free communication in all parts. Just how high these cleats shall be depends on the judgment of the bee-keeper. At one time $\frac{3}{8}$ inch was usual-a bee-space, in fact-but in recent years the pure-air agitation has influenced bee-men, and 80 we find most of them preferring cleats at least an inch high, while some have gone as far as 2 inches. Here is the point: bees breathe, so they must get fresh air, and this enters only through the doorway, the foul air being expelled through the same channel. A fixed shallow entrance leaves no room for extension, whereas a deep one can be readily contracted at any time. But the big space under the frames is a great temptation to comb-building, especially during the honey-flow season. Bee-keepers differ on many details; this is one of them; but in the meantime the tendency is towards giving plenty of room for the admission of pure air. On the surface of the bottom board there will likely be lots of waste matter, such as comb-cappings, maybe dead bees, and all of it should be scraped away.

\section{Tuk: Hive: STAND.}

Lift the bottom board and see what it rests on. Its life is dependent on the absence of two enemies, water and ants; therefore, the bearing surfaces of the supports 

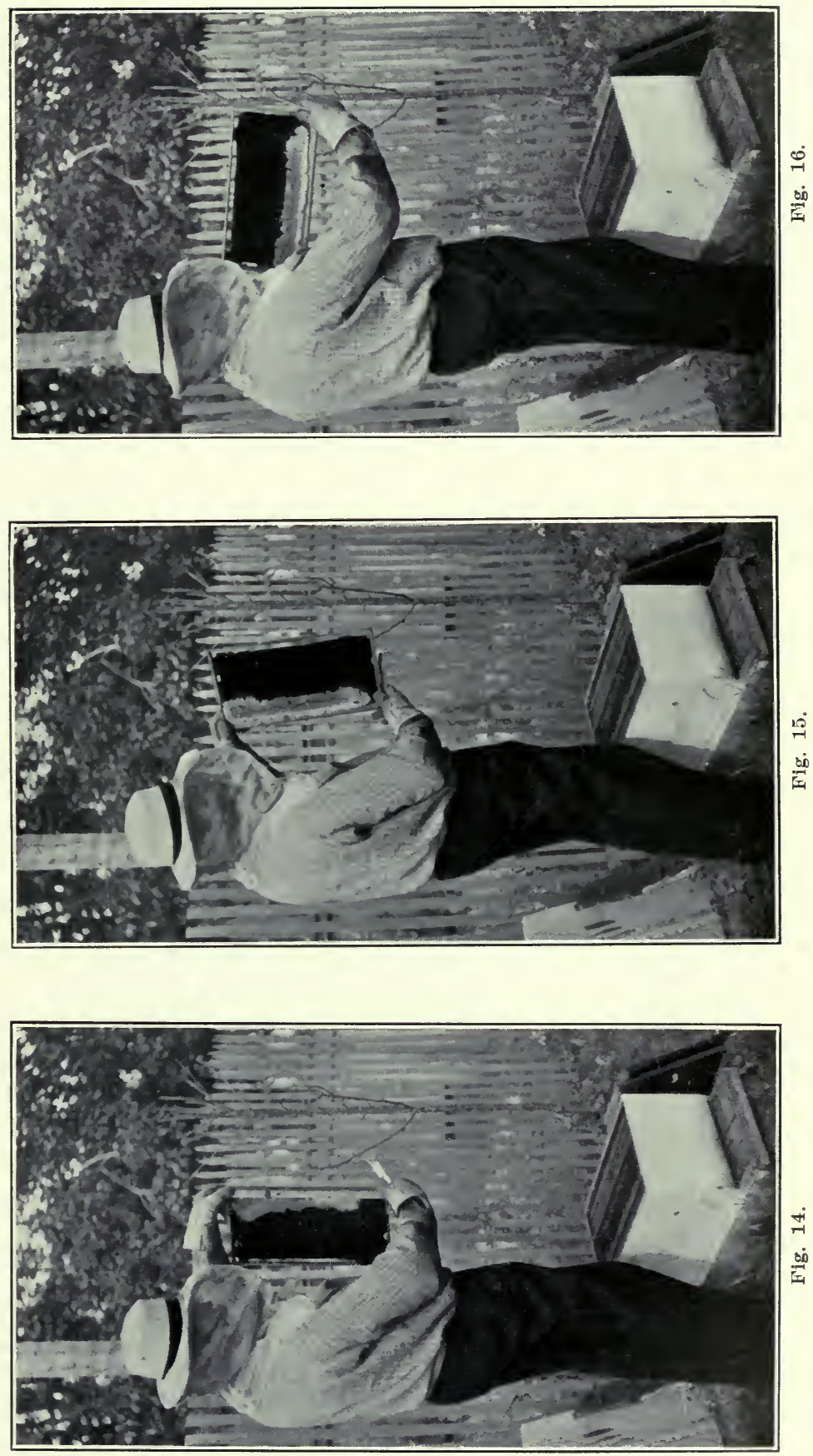
should be as small as possible. Contact with bare earth is very, very bad. Four bricks, one at each eorner, are good, so are a couple of pieces of unplaned $2 \times 4$ lumber a little longer than the width of the hive, one placed under each end of the bottom board. As has already been said, the bottom board must be perfectly level across the frames, but a little higher at the back. No vegetation of any kind should be permitted to grow above its level ; better still, destroy it entirely, as all growth interferes with the flight of the bees.

Our first excursion through a bee-hive has been quite a long one and has disturbed the arrangements of the inmates not only to a considerable extent, but possibly to the injury of the young, for in May it is a rather extensive incubator where as many as 10,000 eggs are being hatched, while 50,000 young bees are being brooded. An open hive means the loss of heat ; therefore, we resolve that in future we will do the necessary examinations as speedily as possible, and never lift the cover unless the shade temperature is about $65^{\circ}$, or warmer.

\section{CHAPTER V.}

The Bee People.

From the dawn of history the greatest intellects have found a fascination in the study of the inmates of the hive, for here is a form of society which elosely resembles that of human beings. Only in recent times has its actual organization been understood with all the marvellous activities that are carried on night and day. The subject is an entrancing one, but this is not the occasion to enlarge upon it ; our business at present is to become familiar with such facts as will lead to success in our aim, which is the production of surplus honey.

The inmates of the hive are of three kinds-queen, worker, and drone. The queen is not the ruler of the colony, as was for centuries supposed, but is the mother of a big

Fig. 17.

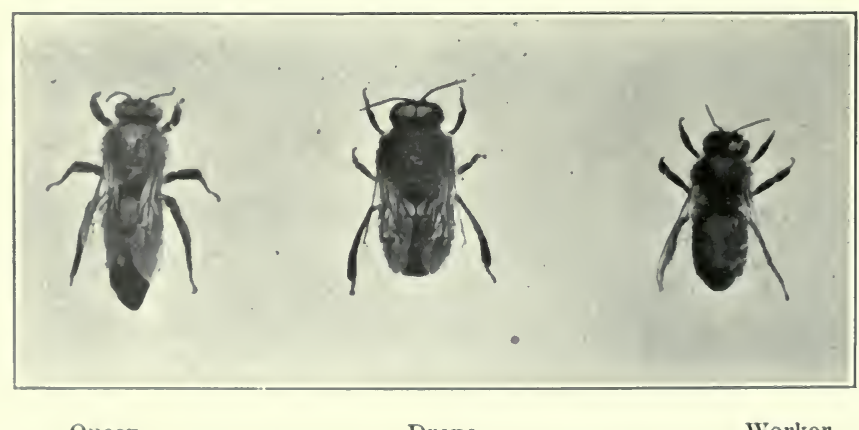

Queen.

Drone.

Worker.

family. Her sole function is to lay eggs, her capacity being literally thousands every twenty-four hours. From October to February she lays very few, but with the advent of the first pollen from the willow in spring she resumes her activity, laying eggs as fast as the worker-bees can take care of them. Ahout May lst the colony becomes strong enough to permit her to develop her full gait, and this she will keep until the honey-flow in June deprives her of the use of the cells. In the fall, as the cells are emptied, she resumes her laying for a few weeks to provide bees for the winter, then enters upon her period of rest. 


\section{The Workers.}

The worker-bees are undeveloped females. They are hatched from a fertilised egg just like a queen, but at the end of the third day of the larval stage they are put upon a less nutritious diet which retards the development of the sex organs, hence they are unfit to become mothers. Their business is to carry in nectar, pollen and water, incubate the eggs, feed the larvæ, do the scavenger-work of the community, ventilate the apartment; in fact, do anything useful that happens to be necessary at the time. In the period of flight they live about six weeks, their short career being due to their intense industry, but those hatched in September and October generally last until April, when their successors appear on the scene. Broadly speaking, the main effort of the community is to have as many producers as possible during the honey-flow, and as few consumers as will keep the community going during the period of dearth.

The Drones.

The drones are the male members of the colony. They are called into existence in late spring in preparation for the mating season, and are mercilessly exterminated at the end of the honey-flow. From their structure they are unfit to gather nectar or pollen from blossoms, so the bee-keeper considers them as merely consumers, and rather costly ones at that; therefore, he limits their number as closely as possible to the actual needs of his apiary. By the use of wax foundation in the brood-frames he prevents the building of drone-cells; should the bees outwit him, he cuts the dronecomb out of the frames.

The mating of a queen with a drone occurs usually only once, when she is but a few days old, the event taking place in the air. When she makes her marriage flight, she flies swiftly away from the hive pursued by thousands of drones, the swiftest of them being the winner of the race ; but he pays for his success with his life, for she deprives him of the sex organs, rupturing his abdomen so completely that he expires almost immediately. As the result of the intercourse, she is able to fertilise the hundreds of thousands of eggs she may lay in the course of her life, which may endure from a few weeks to several years.

Worker-bees are produced from eggs that have been fertilised, but drones are raised from eggs that have not been impregnated. These, therefore, have no father; consequently, any queen that has failed to mate, and this is not very unusual, will be the mother of drones only. Such an one is known as a drone-laying queen.

\section{Development Table.}

The following table shows the duration in days of the various stages of development of queen, worker, and drone :--

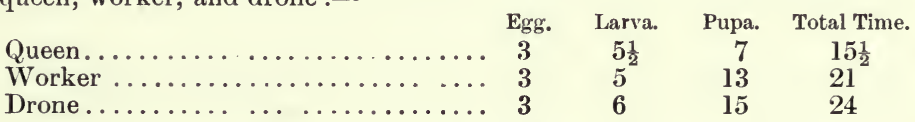

From the start the novice will know the workers, as in suitable weather they are continually moving in and out of the hive. Drones appear about the lst of May. They are bigger than the workers, fly generally in the heat of the day, making a loud hum, from which their name is derived. The queen never leaves the hive excepting to mate or with a swarm ; therefore, to be seen she must be looked for on the frames. She is easily found in the spring months when the colony is weak in numbers, but rather difficult to find in the height of the summer. Once seen she will be readily recognised, as her abdomen is very much longer than that of the bees that surround her. Also, she moves very slowly, especially when she is laying freely, as she is then heavy with eggs. There is but one queen to a hive. 
For the first two weeks of her life the worker does inside work only, her recreation being a short flight along with thousands of her kind round the hive entrance in the heat of the day. These play-spells are sometimes mistaken for swarms coming off, so numerous become the young workers in midsummer. At the end of two weeks the worker becomes a fielder-that is, a provider. It is worth while to note, for it is of practical value in hive management, that five weeks elapse from the laying of the egg to the day when the young worker carries in her first load of nectar.

\section{CHAPTER VI.}

\section{The Cycle of the Bee-year in British Columbia.}

Since bees pass the cold days of winter in a semi-dormant condition, flying freely only on fine sunny days when the thermometer is at least $48^{\circ}$ in the shade, one is tempted to consiler that the bee-year will start with the earrying in of the first pollen, which occurs in the coast regions of the Provinee towards the end of February-in Victoria as early as the 22nd, and in the dry belt a few weeks later; March 12th in the Okanagan. As the probable date draws nigh, even the oldest bee-keepers kindle with enthusiasm and watch for the first bee that is carrying the brilliant-hued pellets on her hind legs. Not only does he rejoice over the prospect of once more being active with a pleasant part of his life, but when he sees bee after bee alighting with her load he knows almost to a certainty that brood-raising has been started and all is well with the queen. If, however, he observes a hive where no pollen is being carried in, while other's are busy, he is suspicious that the queen has died in the course of the winter. $\mathrm{He}$ makes note of all such colonies and at the first favourable opportunity, that is a day when the sun shines brightly, the air is quiet, and the temperature is comfortably warm, rapidly learns whether the colony is queen right or not. Opening the hive, he chooses a frame in the middle of the cluster, looks into the cells to discover the presence or absence of eggs or larvæ. When these are found he investigates no further, but if they are wanting he will inspect the balance of the frames. Failing to find signs of brood, he will then look for the queen, an easy task at this time of the year. If she be located all is satisfactory; if not the case is very suspicious, but it does not do to assume she is actually missing. But if on examination a week later the same conditions exist, then the colony should be combined with one that has a queen. (See chapter 13.)

\section{Essentials in Spring.}

The most essential features of a hive when pollen begins to be carried in are: the sure presence of a queen, lots of bees, and plenty of stores-that is, honey or its substitute, sugar syrup. The lack of a queen means certain death to the colony in a few weeks. A hive weak in bees will develop strength very slowly, or dwindle out of existence, while one without stores may die of starvation or do little more than hold its own during the spring months.

The food supply is largely under the eontrol of the bee-keeper, and at one time spring feeding with sugar syrup was strongly advocated, but in recent years it is considered that the best time to feel for spring consumption is in the autumn of the previons year. So the molern bee-keeper, in September or October, begins to put his bees in shape for the honey-flow in June, by making certain that there are at least 25 pounds of honey, or the equiralent in sugar syrup, in every colony. 


\section{A Simple Diary.}

The bee-year from the apiarist's point of view begins, therefore, in September. But since we have made a little progress with the spring conditions we may as well continue. Every beginner in bee-keeping should keep a diary for the first year, at least as a guide for the future. It need not be in any way elaborate, just a sheet of note-paper lying convenient on which to make brief jottings like these :-

February 22-Willow blooms; pollen carried in.

March 13-A few dandelions; plentiful April 7.

March 15-First examination of hives; temperature, $65^{\circ}$.

April 12-Early pears.

April 18-Early plums; pollen plentiful.

May 3-Nectar and pollen above immediate needs.

May 19-Dearth of nectar; feeding.

June 1-First clover-blossom.

June 19-Honey-flow starts.

These items are simply suggestive, as the apiarist should make it his business and pleasure to know every plant visited by bees in his locality, also their date of blooming. In most regions there are breaks in the flow of nectar and these should be anticipated, as during a dearth brood-raising will be stopped, with serious loss at the time of the honey-flow unless feeding be done. The end of fruit-bloom often marks the beginning of one of these periods.

\section{MARCH.}

Early this month, sooner if possible, lift the hive off the hottom board and clean off the dead bees and other waste matter. The simplest way is to take a spare board, remove the complete hive, place the new board on the stand, then swing back the hive to its place. The operation takes but a minute, so there ought to be no disturbance to the inmates. The old board is now cleaned off and used for the next hive. While lifting the colony one learns roughly its condition as to stores. If light, it must, of course, be fed with as little disturbance as possible, because during this month and next the bees may cluster in a compact ball round the queen-ball her-when the frames are disturbed, and a balled queen is apt to disappear at an early date. Smoke is rarely necessary at this time, provided the bee-keeper is gentle and avoids jarring the frames when returning them to the hive. In the south end of Vancouver Island there ought to be brood in three or four frames about the middle of the month, but, of course, the space occupied by the young in the outside of the nest will be very small.

\section{APRIL.}

In the coast regions, during the latter half of March and the first week of this month, there is apt to be a cool spell, with cloudy or wet weather which prevents beeflight. Brood-raising frequently comes to a stop, so that when the warm weather returns there may not be a single egg in the frames. However, as soon as pollen again comes in freely, the queen resumes her duties, laying so freely that by the 20th there is generally brood in as many as five frames. The young bees begin to hatch out about the end of the month, when they are very much needed, as the old ones that carried the colony through the winter are dying off very rapidly. In fact, for a few days at the end of April the low-water mark of population is apt to be reached; then the tide turns, the working force is rapidly added to, and almost as if by magic the frames become covered with bees. During this month the great source of nectar and pollen in most regions of the Province is the dandelion, but in some parts of the dry belt there is 
complaint of great scarcity of pollen at this time. In such localities a substitute, in the form of some kind of flour, should be provided, as described in the chapter on feeding. Fruit-blooms are a great help in the latter part of the month.

The end of April is a most important period in the development of the hive in most regions, because the bees that will work on the honey-flow will be hatched from eggs that are being laid now. They will become field-workers about.June 4 th, at which date white clover, snowberry, and rhamnus (cascara plant) are in blossom, the nectar in a favourable season secreting freely about ten days later.

Brood-raising at the end of April must therefore be encouraged. Should nectar fail, feeding may be necessary ; on the other hand, it may have come in so freely that the combs become honey-clogged, thus preventing the queen from laying. When this occurs it is a good plan to take from such a hive a frame of honey and exchange it for an empty one fiom another colony. The full comb should be placed next the side of the hive, but the empty frame right in the centre of the brood-nest, so that the queen can proceed to fill it at once. Drone-brood will probably be started this month.

Scrape accumulations of wax and propolis from the top and end bars of the frames.

MaY.

Colonies that are in good condition boom along this month at a great pace. Any hive that on the lst of May shows bees occupying six spaces between frames is in fine condition. Early in the month one must attend to weak colonies if possible. If the lack of numbers is due to a failing queen, the bees may endeavour to supersede her during fruit-bloom, or she may disappear from the hive. Queens riised in a weak colony at this time are of very little value, and are almost sure to be supplanted again in June or July, provided they live that long. There is also great risk that they will fail to mate on account of the cool weather. The writer has had queens hatched out in the end of April and do all right, but the instance is rather unusual. Most bee-keepers have little use for a queen that is not raised during the normal swarming season, or in the time of the honey-flow.

As fruit-blossoms cease there is often a dearth of nectar the last week of the month ; in fact, up until the honey-flow starts, and unless feeding be resorted to, the colonies will dwindle rather than increase. Where broom grows there is no lack of pollen. The dry belt seems to be fortunate enough to have no break once nectar begins to come in.

By the end of the third week of the month a good queen will have brood in every frame, and is anxiously looking for more room. Many, on seeing the hive full of bees, expect surplus honey right away and put on a super; if it be of the extracting variety it will have a queen-excluder below it. Now, as a matter of fact, the honey-flow is not due for several weeks, so the real aim at this date should be to get more bees. The extracting super should go on, but the queen must not be kept out. When given free range she will occupy the new frames at once. The eggs she lays now will provide a magnificent army of workers that will be ready for field-work right in the middle of the honey-flow.

Swarming often starts at the end of May, but this subject deserves a chapter all by itself.

JUNE.

This is the great swarming month. Very strong colonies may send ont a swarm in the early part of the month, but most will start near the commencement of the honeyflow. The new oolony has to build a set of combs, raise thousands of bees and provide stores for the winter; hence the best time to start housekeeping in a new locality is when nectar is coming in freely. 
June is also the month of the honey-flow, so its start should be watched for. The first few days the bees will deposit the nectar in the brood-chamber, filling every vacant ccll just as fast as they become empty through the hatching of brood. Then comes the capping of the honey. This is the time to put on supers, and is indicated by the whitening of the wax on the top of the frames. If comb-honey supers are put on before this, the bees often remove the foundation to use in the brood-chamber. Where an upper division of empty extracting combs was given earlier, and the intention is to run for extracted honey, nothing need be done excepting to make sure that the bees have enough room.

JULY.

In the south end of Vancouver Island the honey-flow comes to an end from the 10th to the 15th of this month. The writer has not got very definite data about other regions of the Province, so each beginner must learn the conditions for himself. On the Island there is no fall flow, but in some parts of the dry belt the bees get a second opportunity to gather surplus in August and September.

Ordinarily there is very little swarming in the coast regions after the beginning of the month, and it is well that this is so, as late swarms will simply starve to death unless fed regularly for several weeks.

All sealed comb-honey should be removed from the hive at the close of the flow, to prevent its delicate whiteness beconing soiled by the travel of the bees. Extracted honey should be left on longer, to insure its being thoroughly ripened. When there is a second flow the crops should be kept apart by extracting the first before the other is due.

\section{August.}

In most regions there is but little forage for bees in August, this being especially true of the coast regions; in fact, were it not for fall dandelions and thistles, there would be practically nothing coming in. Towards the end of the month the second flow starts in the dry belt.

\section{SEPTEMBER}

In the coast districts there is no nectar. Early in the month the hives should be gone through to see how the bees are off for stores. Some bee-keepers feed for the winter before the month closes; others prefer to give half the necessary amount now, the balance a month hence. Any weak or queenless colony should be combined with another.

\section{OCtoвer.}

Before the end of the month make certain that every colony has at least 25 pounds of honey or sugar syrup to carry it through the winter. Feeding over, the colonies should be prepared for the cold months if they are to remain on the summer stand. In the coast region very little protection is necessary ; in fact, most people are content to make sure that no moisture can get into the hive. In the dry belt packing is necessary when the hives are wintered in the open air, as is done in the majority of cases on account of the difficulty of securing a cellar that is dry enough. Only a few report wintering bees in this way.

\section{NOVEMBer.}

When cellar wintering is to be followed, the hives should be transferred to their winter quarters towards the end of the month. 


\section{CHAPTER VII.}

\section{Swarming.}

Living creatures reproduce their kind to insure the perpetuation of the race. (ienerally speaking, the interest is centred in the direct descent from individual to individual, as each one in turn becomes the fountain source of a new generation. But with bees it is different, for here we have a social organism in which the factor of parentage is subordinate. There is continuity from queen to queen, but this is less important than the reproduction of colonies; that is, the fact of perpetuation is more centred in the community than in any individual. Furthermore, a queen may die and be succeeded by her daughter, without any increase in the population of the bee-world at large; whereas, when new colonies are formed, there is an increase both in communities and in the total number of bees.

The bees' method of reproduction, then, is by the formation of new colonies. When the proper season has arrived, generally in June, the hives become very strong with a superabundance of inhabitants, and some fine day thousands of them rush pell-mell out of doors, circling in the air in an ever-darkening cloud for several minutes; then, as if of one mind, they settle in a cluster on a convenient object, which is generally the branch of a near-by tree. Here they cling for quite a while, frequently hours, as if awaiting important news from somewhere; then, if unmolested, they will suddenly decamp to parts unknown, locating in a hole in the trunk of some decaying tree, and there start up the routine of the colony afresh. But in a well-conducted apiary the flight to distant regions is summarily prevented by the bee-keeper, who secures the cluster and houses it in a regular hive. Ordinarily, they accept the domicile, just as pleased as if it were of their own selection. The whole procedure is technically known as swarming.

In a hive in summer-time there are to be found bees of all ages and occupations. The very youngest are nursing the larvæ, making wax, building combs, curing the honey and capping it over; the older ones are field-workers, their business being to carry in nectar, pollen, water, and propolis. An interesting point at once arises, what is the age of the bees that form the swarm? The old queen undoubtedly leaves the hive; that is beyond all dispute; and it is believed that the greater part of the swarm consists of fielders, but there is also a fair proportion of younger ones whose duty is concerned with the inside labour. This should be so, for the best welfare of the new community.

Wach bee fills her honey-sac to its utmost capacity before starting out, so that the new colony is provisioned for several days ahead, should inclement weather prevent the gathering of nectar. On arrival at the new abode, part of the swarm starts at once to clean it out; another gathers into festoons and proceeds to secrete wax; while still others collect the wax and build combs. Just as fast as cells are built the queen lays eggs in them, or the workers store honey, so that in a few days the usual routine of a bee community is established.

In the hive from which the swarm emerged there has been left quite a strong force of bees, thousands of young brood in all stages, from egg to those about to hatch, and several queen-cells, from ench of which there may come out a queen. If the conditions seem propitious, the workers may decide to send off several swarms, each accompanied ly a virgin queen. Since the hive has been decidedly weakened by the loss of the first swarm, the second will be much smaller, the third weaker still, and so on with the others, until the last may consist of a mere handful of bees. Such weak colonies are almost certain to die of starvation during the winter, as they are rarely strong enough to build up a numerous force and lay in sufficient stores before the cold weather sets in, excepting in very highly favoured localities. 


\section{Retrieving a Swarm.}

The handling of a swarm is not a serious proposition, provided it does not settle in a rather inaccesible place. Until it does cluster nothing can be done with it ; therefore it is utterly useless, so far as the bees are concerned, to beat tin pans, ring bells, or otherwise make a hideous noise. Such strenuosity may provide occupation for the beekeeper at a time when he feels he ought to be doing something to show he is in control of the situation, but he will display more wisdom if he sedately waits until they settle, in the meantime providing himself with a bushel or clothes basket and a large apron or similar covering. When the cluster is at the end of a low branch the basket is held close under it, then the branch is given a sudden downward jerk that tumbles the bees

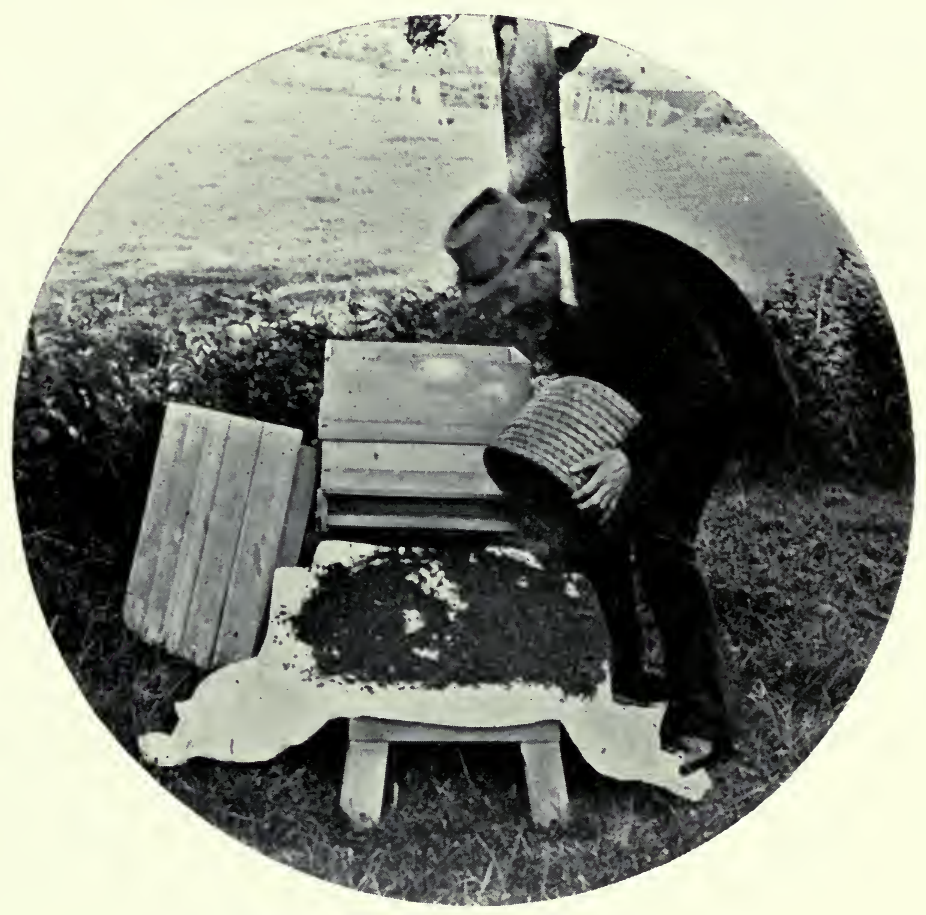

Fig. 18. Retrieving a Swarm.

into the basket, which is then quickly covered with the apron. For a higher branch a stepladder is almost a necessity ; sometimes one must climb the tree to reach the bees. In windy weather they may gather on a thick branch, or even on the trunk, in which case they must be brushed off with the hands. When the branch happens to be a small one the speediest way is often to cut it off. In any case, it is always as well to have a small saw handy when gathering in a swarm, to cut away twigs and sprays that interfere.

Once the swarm has been secured it is carried to the new hive, in front of which a sheet has been spread or boards laid to form a runway. A small lot of the bees is dumped out close to the entrance, the rest farther away, or they may be left in the basket, which is stood on edge leaning against the hive-front. In a few minutes some daring spirit will venture into the entrance and soon all will follow. In warm weather 
it is always wise to have the eover a little raised at the back, to provide plenty of ventilation; otherwise the lack of air may tempt the bees to make a second flight. Do not use smoke while hiving a swarm.

\section{Prevention of Swarming.}

The prevention of swarming is to the bee-keeper a regular will-o'-the-wisp. He wants surplus honey, but he knows by experience that he will get far more from a colony that does not swarm than he will get from one that does, even with the aid of all its offshoots. Therefore, he tries hard to get rousing strong hives by the beginning of the honey-flow, and to hold the forces intact all through the season.

Thousands are wrestling seriously with the swarming problem every summer, striving to understand the immediate cause. It is not enough to say it is the bees' method of reproducing the species, for all strong eolonies in an apiary do not throw off swarms in the season; often the majority do not. Again, it is not a problem of sex instinct, for the queen has no desires but to lay ; in fact, the decision whether to divide or not to divide the colony is determined by the workers, who are free of the sex impulse.

Uneasiness, discomfort, practically sums up the conditions that develop the swarming impulse. It is caused :-

1. By the want of room in the combs, and this is the most important cause of all. There must be readily accessible cells for the queen in early June if the bees are to be contented, hence the importance of giving the colony a second chamber as soon as the bees are crowding the first. To put an extracting super over a brood-ehamber, but with a queen-exeluder between, is no preventive, for this is giving more room for honey when there is none, while it gives no additional room for egg-laying, which is what is wanted. Once the swarming fever has developed, the only cure is swarming, so that giving additional space at this stage is too late.

2. By the heat of the summer sun. This is not enough in itself, but it encourages the impulse.

3. By the presence of an army of drones in the hive, who crowd it and make it uncomfortable. Therefore, keep down the amount of drone-comb.

4. By poor ventilation. It is simply impossible during hot weather for a small entrance to give sufficient circulation of air to satisfy the needs of say 50,000 bees ano alout as many in the baby stage. Therefore, let the entrance after the lst of May be at least an ineh high and as wide as that part of the combs on which the bees are clustered. In most cases this will be the full width of the hive. In the hot weather period the brood-chamber may be pulled back or pushed forward a couple of inches to clear the end of the bottom board and thus give a free current of air under the frames. In extreme cases a through draught in the brood-chamber can be given by pushing forward the super enough to make a crack about a quarter of an inch wide.

5. Colonies run for extracted are very much less liable to swarm than those run for comb honey. Since extracted honey is more profitable in this Province and is produced with less labour, the beginner is advised to devote his energy to securing his crop in this form.

\section{To Prevent Second Swarms.}

The principle involved in the prevention of second swarms is to weaken the parent hive, strengthen the swarm, and secure as much surplus honey as possible. Remove the old hive from the stand and set it in a new location, the sooner the better, as we want to catch all the bees that are coming in from the fields with nectar. Set the new hive in its place, using only starters or full foundation in the frames. Then secure the swarm and hive it in the new hive on the old stand. The bees will at once proceed to 
draw out the foundation into comb. If there be a super on the old colony, next day transfer it to the new one, bees and all ; but if the combs be for extracted honey, place a queen-excluder between the bodies.

The old hive has been so thoroughly weakened that it will have very little ambition to again swarm. The new colony is in possession of practically all the field bees, so will rush in the nectar. There is no room for it in the brood-chamber, since there is no comb ready, so it is stored in the super. Just as fast as the new combs are built below, the queen is ready to take possession and fill the cells with eggs. In the meantime, in the old hive, the bees will probably permit one queen to hatch out and destroy the rest. As young bees are hatching all the time, the colony will get quite strong and possibly lay up enough stores to carry it over the winter.

At one time it was thought that cutting out all queen-cells was a sure preventive of swarning, but it merely delays it. If near the end of the flow, the delay may carry it past the crisis, when the desire will vanish; but if not, then the result is rather problematical.

\section{CHAPTER VIII.}

\section{Frames, Sections, and Foundation.}

A honey-comb is about 1 inch in thickness in ordinary conditions, with a space of about $\frac{3}{8}$ inch between each pair. In a state of nature the bees do not build them in the symmetrical form we like to get in the modern hive; the perfect comb is very largely the work of the bee-keeper. He provides a frame not the least bit like anything the bees would naturally use ; he compels them to build straight, and to start at a certain part of the top bar ; furthermore, he limits their activity principally to the construction of worker-cells, permitting the luxury of a few drone-cells where the bees would make hundreds.

Uniform thickness of comb is secured by a self-spacing device on the upper part of the end bars of the frames, which are there $1 \frac{3}{8}$ inches wide. Now, the bees naturally glue together the end bars where they are in contact ; therefore, the smaller the touching surfaces the better. If you look at an end bar you will see that the narrow side of one is flat, while that of the other is brought to an edge. In the hive a sharp edge is intended to touch a flat edge. Since frames may be turned round we must, in putting the parts of them together, point the sharp edges in opposite directions ; furthermore, we must have a uniform way. The writer, for instance, when he holds up a frame for inspection, as in Fig. 10, has the sharp edge against the fingers of his right hand, but against the thumb of the left.

If a swarm be hived on perfectly empty frames, there is no reason, frum the standpoint of the bees, why they should build a comb from the top bar of each and that truly in the centre. The bee-keeper forces them by fastening artificial foundation along the centre of the bar, and once they have begun they will naturally carry the comb straight down to near the bottom bar, sometimes all the way. Through motives of economy many bee-keepers use merely a strip of foundation, say an inch wide, but the presentday tendency is to use full sheets in each frame : first, to be sure of getting evenly-built combs; second, to prevent the building of drone-cells. There are many conflicting theories as to how the bees decide when they shall build drone-comb, but this much seems to be true : a swarm provides worker-cells at first so that the queen may start laying, and will build no other kind for twenty-one days if she can use each cell as fast as it is made ; but at the end of that time the cells first occupied are again empty, hence she may be unable to keep the new ones full, and then the comb-builders may turn their 
attention to drone-comb. When there is too much of this-a pateh as big as the palm of one's liand is enough for any hive-it should be cut out, in the hope that it will be replaced by worker-cells. The best way, however, is to start right by using full sheets of foundation in each frame. The cost is about 10 cents a sheet, which is soon saved, since there will be no army of drones eating up much more than that value in honey, besides helping to arouse the swarming fever in the minds of the workers.

The sheet of foundation is inserted into a narrow groove cut in the under-side of the top bar, then held in position by a wedge alongside of it. This wedge must be driven in very tight.

In a fine specimen of a finished frame the comb is attached to the bottom bar and the two end bars; but, unfortunately, such fine examples are not as common as they might be. Now, a comb filled with honey and brood weighs several pounds, so that

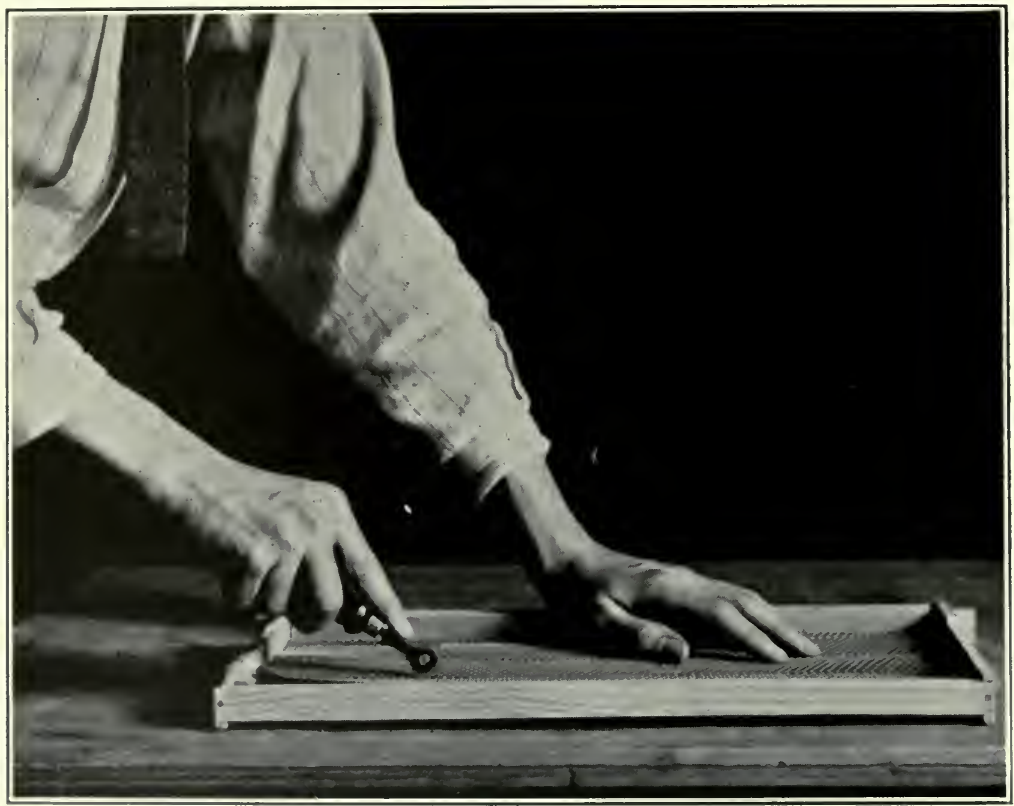

Nig. 19. Embedding Wire in Foundation.

there is quite a strain on the upper part; furthermore, if it be tilted from the perpendicular it is apt to break and drop out of the frame. To hold it securely in position, the frame is usually wired. For this purpose the end bars are pierced with three or four holes, through which the thin wire is strung. Of course, the wiring is done before the foundation is put in. An unwired frame should never be run through the extractor.

'The operation of wiring is a very simple one. Where three wires are to be used, begin by driving in half-way a couple of taeks, one beside a hole next the top bar, the other alongside the hole nearest the bottom bar at the other end of the frame. These taeks mark the position of the two ends of the wire when it is in place. We want the wires to be so tightly strung that when the joh is finished, if we pluck them as if playing a harp, they will "sing." The easiest way to secure the proper tightness is to nail a couple of cleats on the bench, whose distance apart shall be a little less than the length of the bottom har, then spring the end bars between these two. Wiring drawn tight 
with the frame in this position will be more so when the frame is released. As the wire is rather inclined to kink, it is better to pass it first through the centre holes, then through the top ones, finishing off this part of the work by winding the end round the tack next the top bar. Now pass the other end of the wire through the bottom holes, draw every strand tight, then twist the end round the second tack. Remove the frame from the eleats and finish the job by driving home the tacks.

Once the fuundation is in place the wires should be embedded in it, by means of a wire embedder, which is a small wheel on whose rim are spurs set alternately. These straddle the wire, which is forced into the foundation as the wheel is passed along. To secure a firm support for the foundation, lay it on a piece of $\frac{3}{4}$-inch board, a little smaller than the inside dimensions of the frame.

\section{Sections.}

Most beginners in bee-keeping choose comb-honey as the preferable form of the erop, probably because they hesitate to invest in an extractor until they learn what prospects there are in the venture. The production of a fine article of section-honey in paying quantities is the acme of expert bee-keeping, and that too in favourable regions, but this Province is not one of them, on account of the cool nights. The making of a section is accompanied by much comb-building, which calls for a high temperiture in the super at night, a difficult matter when the outside atmosphere is cool. The production for other reasons is difficult in some parts of the Province, so that, all in all, the results from this form of honey production eannot be considered as a guide as to the possibilities of the locality or the suitability of one for the industry.

The section in general use is $4 \frac{1}{4}$ inches square, the width is $1 \frac{7}{8}$ inches, with bee-way at top and bottom to give the bees free access to the comb. Of course, there are many other styles, but the one described is the one most likely to be carried in stock by local houses. A special body called a super, because it is placed above the brood-chamber, is used to hold these sections. It is $4 \frac{3}{4}$ inches deep, otherwise it is the same size as an ordinary hive. A beginner is apt to be puzzləd with the descriptive names given to a super, but he must remember they are got from the hive. Thus, an eight-frame super is intended to go on top of an eight-frame hive. In this surplus chamber the sections are earried in holders, a kind of frame, in fact, with separators between, whose purpose it is to secure uniform thickness and evenness of comb. A couple of springs between the last separator and the side of the super hold everything tight.

Though devices exist for folding sections-in fact, are a necessity where many thousands are used-in a small way the folding is usually done by hand. Since the joints are very thin and brittle, it is necessary to wet them a little while before they are bent.

As with frames, foundation must be used, starters at least, say an inch wide, and very thin. Brood foundation is much thicker, but the proper kind for either purpose is carried by all dealers in bee supplies. When several thousand sections are needed, a machine will be found a great convenienee, such an one as a Root's Daisy Foundation Fastener, which costs about a dollar. But where only a few are wanted the starters can be readily fastened in with melted wax. One way is to attach the starter to the top part of the section--that is, one of the sides in which is the bee-way-before the wood is folded. First, with an ordinary jack-knife cut the wax foundation into strips $3 \frac{7}{8}$ inches long and 1 inch wide; then melt some wax in a shallow dish set on boiling water; lay the sections in a pile, face up, on the bench in front of the melted wax. Now take a starter, dip a long edge in the wax for a second, then set in position on the section. Some who can work swiftly find this plan all right, but the writer is not quick enough, for by the time he gets the starter in position the wax is set. A surer 
plan is to run a line of melted wax along the edge of the starter while it is in contact with the wood. Hold the starter with the fingers of the left hand, run the wax with a teaspoon held in the right hand. The most certain way is to make a special jig for the job. First, out of $\frac{7}{8}$-inch wood cut pieces $3 \frac{3}{4}$ inches square; about a dozen will be enough. Then nail these an inch apart on a board. Now you can hang the folded sections on these, upside down, place the starters in position, then run the wax along the edge. A slight backward tilt to the board is an advantage. The wax will set very quickly, but it takes a little while for it to harden, so handle each section carefully while setting it aside.

\section{Extracting Combs.}

Extracted honey is produced in ordinary combs, just the kind used in the broodchamber. While new they are rather tender, therefore many will not use a comb for extracting purposes until it has been bred in at least one season. The colıur of the comb in no way affects the colour of the honey. To get first-class combs they must be built during the honey-flow. The frame filled with foundation is placed between two old combs, either in the brood-chamber or super. We have already seen that spare sets of empty comb are of great value in May, when they come in very handy to give the queen more room.

\section{CHAPTER IX.}

\section{Securing the Harvest.}

Everything needed for the honey-flow in June should be got ready in May, at the latest. When a swarm is clustering on the limb of a tree is not the time to rush to town for the needed hive, yet such has happened many times in the history of beekeeping. It is just as bad to put off the making ready of supers until the honey-flow is on. One cannot turn the mill with the water that has gone, neither can the bees gather the nectar that was in the blossoms yesterday, but which they could not store away on account of the lack of room in the hive. Besides, they have learned to loaf and to think of swarming, both bad habits from the bee-keeper's point of view.

So be prepared for whatever may come, whether a flood or a failure. If you are running for section-honey, have for each hive at least two supers ready, filled with sections, and, in addition, have at least fifty more sections in the house. One famous bee-keeper in an ordinary region says he has five section supers for each hive ready every season, even if he finds them necessary only once in half a dozen years. Once he found that number not nearly enough.

When the flow starts the problem is to get the bees to work in the section supers, for they do not take to it kindly on account of the restricted passages to which they are unaccustomed; often they will rather swarm than take possession. When a hive has been so strong that the bees occupied two brood-chambers, they have learned to carry the nectar above; so if we remove the upper one-of course, making sure that the queen is left behind-then put on the comb super, it is probable the honey will be stored in the sections. The upper division may be placed above a weak colony to strengthen it, or the frames of brood distributed where wanted. The flying bees will return to the old hive.

Bait sections are often used to decoy the bees above. The unfinished sections from last season are kept over the winter, and at least one is placed in the centre of each super; more is even better. But if the honey-flow is not started when the bait sections are given to the colony, the homey will be removed and nsed below to feed the brood. 
The sections in the centre are the first to be filled. It does no harn to remove them as soon as they are finished, filling up with empty ones. If you leave them alone until all are done, watch their progress just the same, and as soon as you see that the super is more than half-full, put a second on top of the first. Further actions will depend on conditions. Should the first super be completed before the end of the flow is in sight, then empty it, fill in new sections, and set above the second. If the end is near, go slow, for you want finished sections, not a lot in various stages of development.

The removal of a super full of sections in the midst of the honey-flow is a simple affair ; just take it off the hive and set it on end on top of the cover. In an hour or two the bees will have vacated it, returning to the hive, nor will other bees bother, as they are too busy carrying in nectar. But when the honey-flow is over it is a very different affair, for then the worker-bees are looking for a chance to rob each other's

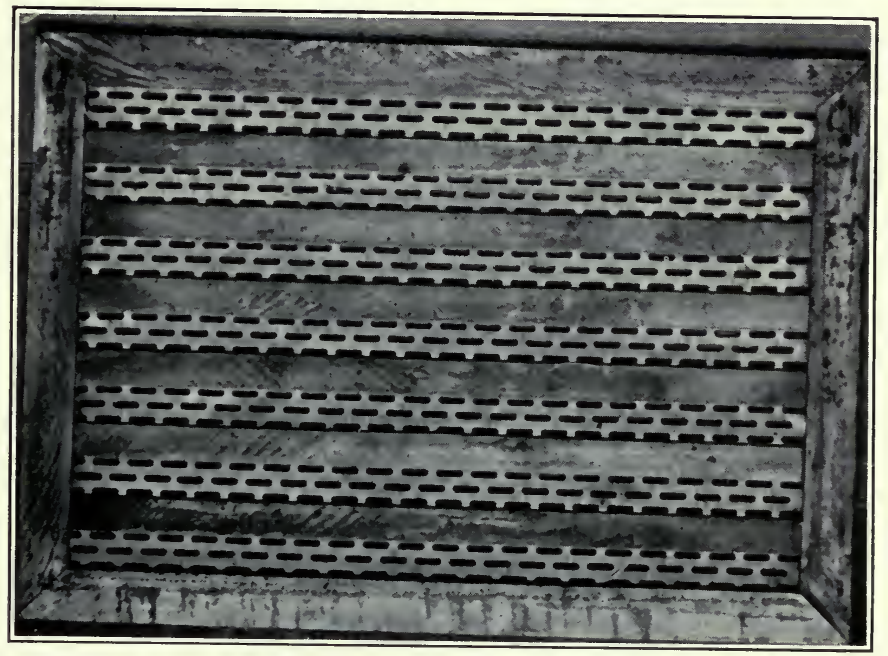

Fig. 20. Queen Excluder, or Honey Board.

hives. The super must be at once cleared of bees by jarring it, also by the use of smoke, but the less of this the better, so as to avoid tainting the honey.

Section honey should be sold as speedily as possible, before it has time to granulate. When stored in a hot, dry place it will probably remain liquid until Christmas, sometimes much longer, but, all in all, the early market is the safest.

Sections intended for sale should be scraped clean of all propolis and wax. A jack-knife with a straight blade is a good tool for the purpose. The agricultural world cannot learn too soon what is well known in the industrial sphere, that more money is spent to gratify the eye than on all other sense organs combined; therefore, it pays to have clean and neat every article that is to be placed on the market.

\section{Extracted Honey.}

When the queen has the run of a couple of hive-bodies there is nothing to be done at the commencement of the honey-flow, unless the bee-keeper wants to confine her to the lower chamber. In this case he gets her below, then places a queen-excluder between the two parts of the hive. The bee-keeping world is very much divided on this question; some men use the excluder, just as many do not. It is the nature of the bee to store the honey above the brood; therefore, when they have been occupying 
two divisions, it is natural for them to start storing in the upper one, occupying the brood-cells as quickly as they are vacated. At the end of a good flow the upper division will be entirely free of young. When the super is half-full, a second one should be inserted between it and the brood-chamber. It is well to leave the honey on the hive for several weeks after the flow is over, so that it may thoroughly ripen, for green honey is very apt to turn sour.

The honey is removed from the comb in a machine called an extractor. After the cappings have been cut from the cells the frames are set in the baskets of the machine, which are then made to revolve at a high rate of speed, quick enough to throw the honey out of the rombs against the sides of the can. An extractor suitable for Langstroth frames and big enough for a small apiary will probably cost, delivered, about $\$ 16$ or $\$ 17$.

\section{Taking: the Combs from the Hive.}

The actual work of extracting is best done on a warm day, as the honey is most liquid then, and in a room from which bees are excluded by a screen-door. Removing

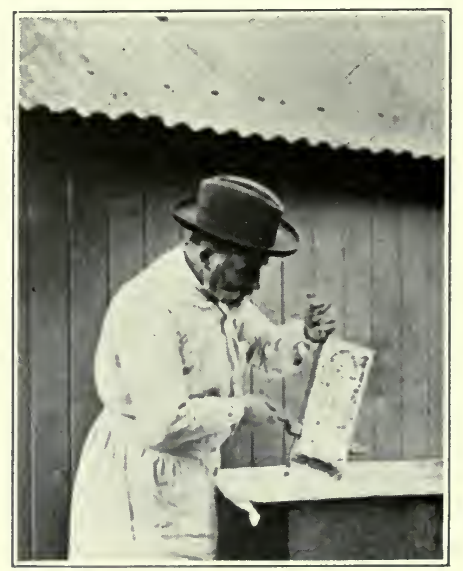

Fig. 21. Uncapping Comb.

the frames from the hive is to most beginners a rather serious problem, on account of the multitude of bees on them. Go about the task in this fashion: Smoke the bees down anong the frames. Take out the first frame and shake the bees off it at the entrance of the hive, then place it in an empty hive, which should be standing on a wheelbarrow elose by. Draw the second frame towards the side, so as to make a gap between it and the next frame. Into this pass a whisp of long green grass, or a switch brush, and so wipe most of the bees off the comb. Lift the frame and shake off the remaining bees into the vacant space, then set it beside the first frame in the hive on the barrow. Treat the balance of the frames in the same way. The empty body is now removed-of course, supposing that the honey-flow is past; if not, it must be refilled with empty frames. Now wheel the load of combs to the extracting-room and do not worry about the few bees yon may carry in, for they will soon try to get out by door or window, and not bother you at all.

Uncapping is done by a long, very sharp knife; a butcher knife is good, but one can buy a style specially designed for the purpose. Old combs are rather tough, so it is often necessary to heat the blarle of the knife, which is hest done by placing it in hot water when not in actual use. In uncapping, the idea is to eut a slice from each side 
of the comb, starting at one end of the frame and working to the other, using a kind of saw motion, as in cutting bread. The frame is stood endways on a support, the upper end of the top-bar being grasped by the left hand. Some workers cut upwards, tilting the frame away from their body, so that the slice will hang clear of the comb as it is cut. Others prefer cutting downwards and appear to have no trouble with the cappings ; these are caught in a vessel below. The uncapped combs go into the baskets of the extractor, one to each; the handle is turned swiftly for a few minutes, thus emptying the outside cells; the frames are reversed, then the other side is freed of honey. The faster the baskets travel the more efficient will be the work of the machine. Just a word of warning to a beginner. Do not worry if you cannot see lots of honey after you have run through the first pair of combs, for remember it is spread very thinly over a large surface, but in a little while it will gather in the bottom of the can. The set of empty combs should be returned to their former position on the hive for a night, to be cleaned up by the bees, then stored away until wanted next season.

The uncapping device should be so made that it will give the cappings a chance to drain. In a small way one can use a large pail in which is set a cheap barrel, in the bottom of which a number of inch holes have been bored. Next take a piece of $1 \times 4$-inch wood a little longer than the barrel is wide, and through the middle of it drive a strong nail that will project an inch at least. Sharpen this point with a file. Fasten this board across the mouth of the barrel, nail point up. During uncapping rest the end bar on the point of the nail. The cappings will drop into the barrel and drain into the pail below. What to do with the wax will be told later.

The impurities present in extracted honey consist of fragments of wax, pollen, parts of bees, such as wing or leg, also occasionally a few larvæ. The first mentioned are all lighter than honey, so will in time rise to the surface; so in the case of a small run the honey may be allowed to stand in the machine for a day before it is drawn off. A piece of clean, strong muslin tied over the faucet makes a good strainer.

Bulk-extracted honey is generally stored in cans. The chief point to remember is, seal the can tight to keep the aroma in and moisture out. Honey absorbs moisture from the atmosphere, becomes thin as a consequence, then ferments and turns sour. In air-tight vessels well-ripened extracted honey will keep for many years.

Most honeys granulate-that is, candy-in a little while. To liquify, set the can in a dish of water on the stove, but with pieces of wood between the can and the bottom of the vessel. Melting is slow, but if there be no hurry it is a good plan to leave the can of honey above the water-tank that is found in most stoves. Of course, the cancover should be loosened.

Honey that has been melted does not granulate so quickly as at first. The higher the temperature to which it is raised the longer will it remain liquid, but if made too hot the colour will change to amber. The average buyer of honey in small quantities does not like to be bothered with the melting of it; therefore, it is a good plan, before putting the honey into jars, to bring it to a temperature of $150^{\circ}$ to $160^{\circ}$, never more than the latter. 


\section{CHAPTER $X$.}

\section{Feeding.}

We have seen that in the spring months the bees build up a huge army of producers to secure the benefit of the heavy flow of honey in June. All during the breeding season every drop of nectar is converted into more bees about as fast as it is brought in; then in June and July every cell in the comb is plugged full of honey, on which they will have to subsist until dandelions bloom in spring. But the bee-keeper finds a ready market for the toothsome honey, and therefore robs the hives of the stores, not infrequently leaving too little for the bees to winter on, with the natural result that, unless other provision is made, the colony will starve to death. Again, for some reason the bees may have consumed stores in the winter much more rapidly than was anticipated, so that they must get help in the spring. We have also seen that at the end of fruit-blossom there is often a dearth for a few weeks which would put an end to brood-raising unless the bee-keeper lent his aid. In each instance the necessary assistance is given in the form of sugar syrup, made from the best granulated sugar; any other kind is risky.

The feeding in the fall for winter and spring consumption is the most important. About the leeginning of September an estimate should be made of the amount of stores in each hive, this being done by examining each frame and sizing up how many seetions of honey it is equal to. Roughly speaking, an ordinary frame will hold eight sections of honey, each weighing about 14 ounces, let us say a pound. To be in safe eondition, each hive should contain about 25 pounds of stores. For every pound short of that amount, feed 1 pound of sugar dissolved in water.

Fall feeding is usually done quickly - that is, large quantities of syrup, often as much as 25 pounds, are given at one time. Some men give the full amount needed about the middle of September; others give half then, the other half about the end of October.

The syrup fed in the fall is made rather thick. The thinnest ever used is got by taking equal quantities, by measure, of sugar and hot water, boiling, if possible. It is important to dissolve the sugar thoroughly, so stir well. Some bee-keepers, for fall feeding, use as much as two parts of sugar to one of water, but this strength should not be exceeded.

In the spring months a very much thinner syrup is better, one composed of two parts of hot water and one of sugar. This is given slowly, say from half a pint to a pint a day, aceording to the needs of the colony.

FEeiders.

There are four methods of feeding-namely, open-air, above the brood-chamber, in the hive, and below the brood-chamber. Open-air feeding has several limitations. One is apt to feed other bees if there be any within a couple of miles; then there is a temperature limit, for the writer finds bees will not take up syrup from below unless the thermometer is above $50^{\circ}$, so that the same conditions will probably apply to the open air. Feeding below the hive has much to recommend it with suitable dishes, but on the eoast regions it is unfortunately impracticable in the spring months, as there are often weeks of cool weather. For fall feeding this system is all right. For giving syrup in spring, preference should be given to a feedler that fits into the brood-chamber, where the syrup will retain the heat and be readily got at by the bees. In the fall it is usually most convenient to feed from above.

There are many devices by which syrup ean be given from above the brood-chamber. Perhaps the simplest is the ordinary frietion-top can, such as is used as a container for syrup, jam, ete. P'repare it by punching the lid fairly full of small holes with the point 
of a nail. Fill the can with the syrup, put in the top, set the can upside down on the top of the frames. As many cans as the frames will hold can be used at once. The bees will carry the syrup as fast as it leaks out. Of course, an empty hive must be on top of the hive to hold in the heat and to prevent bees from other hives getting at the supply. A Mason jar will do just as well. An excellent top-feeder on the market is known as the Miller. With it 25 pounds of syrup can be fed at one time.

For spring feeding the writer recommends the Doolittle division-board feeder, which is placed in the hive alongside the brood-nest like an ordinary frame. The

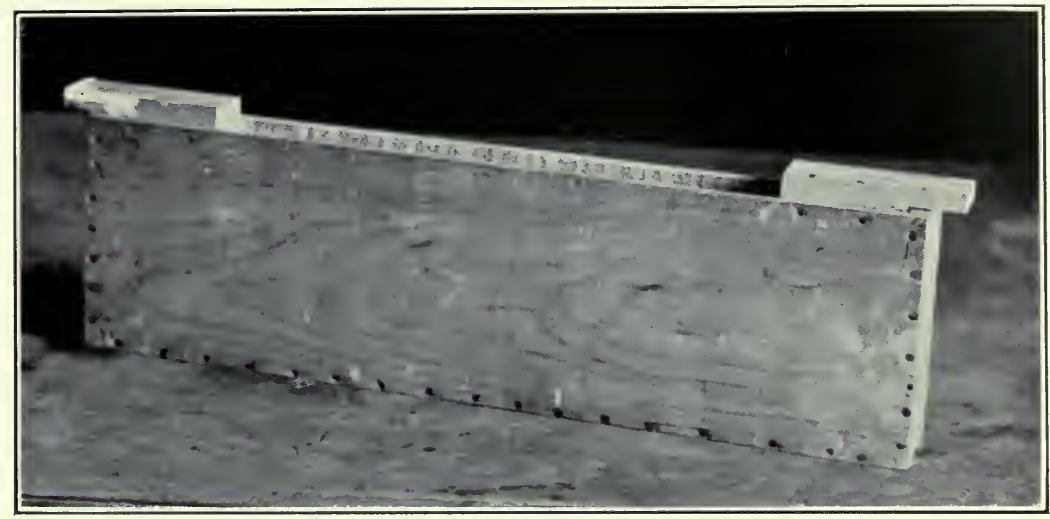

Fig. 22. Division-board Feeder.

illustration will show its construction. The sides are made of $\frac{1}{4}$-inch wood, $5 \times 17 \frac{5}{8}$ inches, rough on the inside to give foothold to the bees. The bottom and end bars are of $\frac{3}{8}$-inch wood, $1 \frac{1}{4}$ inches wide. The end bars are 5 inches in length; the bottom bar is $16 \frac{7}{x}$ inches. Each joint is coated with thick paint before nailing. For the lugs cut two pieces of $\frac{3}{4}$-inch wood, $1 \frac{1}{4} \times 3 \frac{1}{2}$ inches. From one end of each piece eut a check $\frac{3}{8} \times 1$ inch. This feeder will drown bees unless a slat is put inside of it to float on the top of the syrup. To fill the feeder, turn back the quilt sufficiently far, pour in the syrup, then replace the quilt.

\section{Feeding a Pollen Substitute.}

In some parts of the dry belt there is a lack of pollen in the early spring months, so that in the ordinary course brood-raising is seriously hindered. The bee-keeper in such a region can provide a substitute in the form of finely ground, dry, unbolted rye meal, or even ordinary flour, which is set out in shallow troughs or boxes. The layer must be quite thin, otherwise the bees will drown in it. To attract the bees, smear a little honey on the edge of the tray. The boxes must be placed in a warm spot, sheltered from the wind. Continue feeding until the bees cease to use it, which will be when the blossoms provide the real article.

Various methods have been devised for feeding artificial pollen inside the hive, but in practice they are found to be injurious to the welfare of the colony. 


\section{CHAPTER XI.}

\section{Preparing for Winter.}

Since bees fly at $48^{\circ}$, the ideal temperature for wintering is one a few degrees less, say $45^{\circ}$, for in this they would consume the minimum of stores, since honey is to them, of course, the souree of heat. In regions where the temperature falls below zero it is a eommon practice to winter the colonies in a cellar, most of which is underground, but with eareful packing the bees do all right out of doors in the same localities. In the dry belt of this Province, hives that are to be left on their summer stand must be packed for the winter. T'he easiest way is to construct a bottomless box out of cheap material large enough to give a free space of 6 inches all round the hive when it is in position, say $24 \times 32$ inches, 20 inches high. Cut out enough from what will be the front to give free access to the entrance.

Now get a sufficient quantity of dry leaves, straw, exeelsior, or shavings. First pack tight underneath the hive, then place the box in position, fitting in a piece of wood to prevent the packing coming down over the entrance. Now fill up all round the hive, ramming the material in tight; next over the top. The latter is the most important part of all, because heat travels upward, so be sure to get enough protection on top. When full, nail on a cover, which must be watertight. Use paint, tar-paper, or eanvas to keep out the wet.

The size of the entrance for winter is one of these points on which bee-keepers differ very decidedly, some advocating one the whole width of the hive, while others prefer one about 3 inches long by $\frac{3}{8}$ inch high. The tendeney is apparently towards giving plenty of air but without dranghts.

In the coast regions many bee-keepers content themselves with no special protection at all, simply leaving the hives as they happen to be at the beginning of winter. Others place two or three strips of lathing across the frames to make easy travel from one part of the hive to another in the warmest part ; on these a quilt of sacking; then an empty super, which is packed with anything that will hold in the heat. The eover must be fastened securely, so that it eannot be blown off in the winter gales.

Still another method is to wrap thin tar building-paper round the hive. Take off the cover, put on a few layers of sacking above the frames, then put the paper round the hive, leaving the surplus sticking up above it. Strings are worthless for protecting the paper; strips of wood are much more satisfactory. Place one along the edge of the overlap, fastening with a couple of nails. Fold the projecting pieces of the paper over the sacking and replace the eover. Finish off by nailing strips of wood, such as lathing, on the paper at the lower elges of the hive. This covering need not be removed until well along in May, when the bees are strong.

\section{CHAPTER XII.}

\section{Queens.}

The average beginner naturally makes no effort to eontrol his bees in their natural impulse to inerease by swarming, but one season's experience of retrieving swarms, and of investing money in new hives, with not infrequently very little returns in the shape of honey, will soon arouse a desire within him to beeome master of the situation, so that increase shall be when he wants it and to the extent that will suit him. To attain this desirable end he must lenrn $n$ few simple facts about the life history of the queen, from the egg to the time when she begins to lay. 
We have already learned that the egg îrom which a queen is to be raised differs in no way from that from which the ordinary worker develops. Furthermore, it hatches out the same, and for three days the young larva is fed like a worker-larva, but on the fourth day the latter is put on a less nutritious diet that prevents the development of the sex organs. The food of the royal larva remains unchanged; its quantity is lavish; with the result that the full development of the insect is secured, not only organically but in actual size. Since she is to be larger than either worker or drone, the ordinary cells of the hive are not big enough, hence the bees must build a special cell for each young queen, which is known as a queen-cell. Fig. 23 will show how they look. In ordinary course, a populous hive will make preparations for swarming by starting a number of royal cells, usually placing them on the edges of the comb that are not

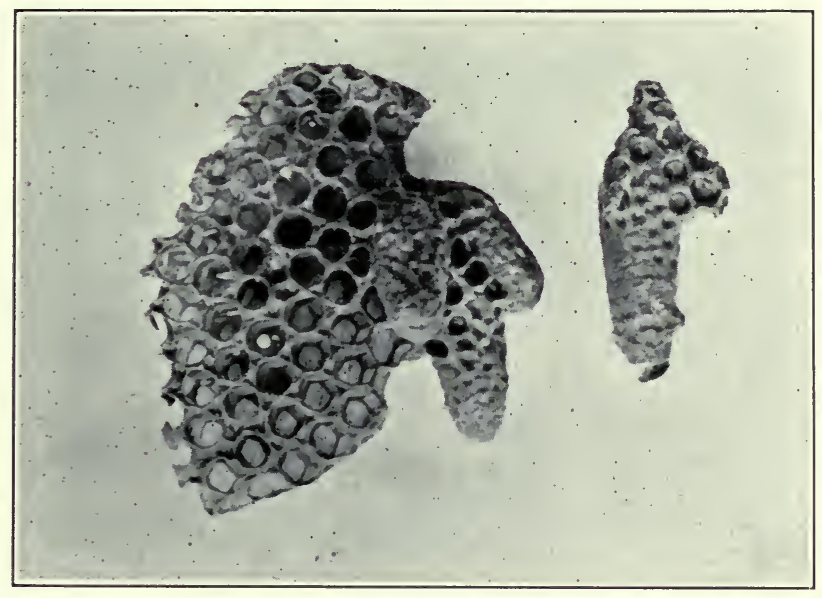

Fig. 23.

Queen Cells.

attached to the bars of the frame. When complete they somewhat resemble a small peanut, and are about an inch in length. When first started they rather suggest an acorn-cup ; in fact, after their usefulness is past they are usually trimmed down to about the same size. While all other cells are horizontal, queen-cells always hang perpendicularly, with the mouth downward. The number in a hive varies greatly ; sometimes there are only a couple, generally about six, occasionally as many as a dozen.

In due course an egg will appear in each cell, but not all at the same time, as two queens cannot be free in the same hive together. One will certainly kill the other.

When the first cell has been capped over the first swarm will come forth, accompanied by the old queen. A week later the second swarm is due, this being headed by the first of the young queens. Others may follow at intervals of a day or two. As eaeh virgin hatches out she tries to get at her rivals in the cells, and if successful stings them to death. Whether she reaches the others or not depends upon the bees, who hinder her progress or give free access as suits them. In any case she issues a challenge, in the form of a shrill peep-peep-peep, which is responded to by the most advanced of the others, but since they are confined in a close chamber the sound is more like quaqua-qua. When a second swarm is due one can hear both sounds by placing one's ear in contact with the side of the hive. The second swarm having departed, another queen is released. Should both sounds be again heard, a third swarm is likely. But if the bees feel there has been enough of swarming, the other queens will be killed. Many bee-keepers, after the first swarm has issued, open the hive and destroy all cells except the largest one, and so prevent any more. 
Should a hive in the breeding season become queenless, either through the death of the queen or through her removal by the bee-keeper, the bees at once proceed to develop a successor from the young larve and eggs on hand, building the cells on the faces of the combs. Should they send out a swarm it will be headed by a virgin, and, of course, the second one will come forth a day or two later.

The facts in the last paragraph give us the key to making increase under the control of the bee-keeper. A simple method, but rather wasteful, is to divide a very strong hive into two parts, leaving one-half on the old stand and setting the other on a new one. The half without a queen will at once start queen-cells. The drawbacks to this plan consists in the probable loss of young brood through neglect in the part that was moved, and in the slowing down of egg-laying by the queen.

Here is a much more efficient way: Remove the hive from the stand and in its place put one containing only empty combs or foundation. Take out the centre comb, then turn to the old hive and look for the queen. When she has been found, set the frame she is on in the centre of the empty hive. Put a queen-excluder above, then on top place the old hive, into which now put the empty comb from the lower one ; replace the cover. Leave the combination alone for five days, then look carefully over the combs in the upper body to see whether or not queen-cells have been started. If such are found, carry the upper story to a new stand. We have gained much in the five days. The queen has been stopped but little; much of the brood above has hatched, lessening the cares of the workers there, and there is an army of young bees in the upper division that will stay where they are put. When no cells are started, leave the hives together for five days more. After moving the upper story to a new stand it must be provided with a frame containing larvæ and eggs, for, of course, all its own larvæ are too old. This frame may be taken from any hive, preferably from one that is noted for good workers. Shake all the bees off the frame, to make certain you do not carry the queen with you.

As many queens get lost in the mating flight, it is always advisable to examine a hive about twelve days after the queen hatches out. If eggs are found, things are probably all right; but if no eggs are present, then give a frame of brood with eggs from another hive, so that, if necessary, another queen may be raised.

\section{CHAPTER XIII.}

\section{Diseases.}

Bee diseases are divided into two kinds, those that attack the mature bees and those that affect the brook.

The adults are liable to diarrhoea, paralysis, and a vague one in the early part of the season that is generally called "spring dwindling." Diarrhota frequently occurs when the bees have been compelled for several weeks to stay in the hives, especially on poor stores, such as fruit-juices and honey-dew-the latter being an excretion from aphids and scale insects which is sometimes plentiful in the autumn in the coast regions. Honey.dew is usually very dark, often granulates quickly, and has an unpleasant taste. When in health, bees empty their bowels only when on the wing, but when flight is hindered for some weeks the evacuation may occur in the hive. This is the reason why bottom boards should be cleaned off early in spring, so as to get rid of the germs. 
Bee paralysis is not a common disease in cool climates, but there are a few reports of its occurrence in the Province. The sick bees look black and greasy, and have a very swollen abdomen. They generally stagger around as if paralysed. The disease is supposed to be constitutional, so the usual remedy is to destroy the old queen and introduce another from a healthy stock.

Spring dwindling is a term that may cover a multitude of troubles. There is undoubtedly a germ disease affecting the intestines that sometimes develops in the spring months, but not much is definitely known about it. Dwindling may, however, be due to lack of bees-that is, not a sufficient number to keep the hive warm enough for brood-raising, or from want of stores-either honey or pollen.

Brood Diseases.

The diseases that attack the larvæ are American foul brood, European foul brood, and pickled brood. Both of the forms of foul brood are very deadly, and once they get a foothold in a district they will, if unchecked, wipe out every colony. The bees themselves are unable to cope with them; hence it is utterly futile for a bee-keeper to conceal the fact that there is something wrong with his bees, in the hope that the trouble may disappear. If left alone, a slight case of infection, once it gets headway, will spread, not only over every colony in that apiary, but in the district. The writer cannot speak too strongly on this subject, especially since at the time of writing, the Province is probably free of these diseases. But continued immunity will be got by vigilance only, for in the older settled regions of the Dominion and in some parts to the south of us a fierce fight is being carried on with foul brood. This Province is free because it is young. To keep it free, the introduction of contagion must be prevented as far as possible. Every bee-keeper can help by following two simple rules : First, not to bring into the Province any hives of bees, empty hives, or used appliances of any kind; second, never to feed honey to his bees unless he knows for certain that it was produced in an apiary free of disease. The germs of foul brood are present in the combs and honey, so that the reasons of the above recommendations are very apparent. Furthermore, at the slightest hint of diseased larvæ being found in his own hives or those of another, every bee-keeper is earnestly urged to at once notify the Department of Agriculture, so that steps may be taken for its eradication.

\section{American Foul Brood.}

American foul brood has been so named because the germs that cause it were first isolated on this continent. The symptoms of the disease are thus described by an authority :-

"Some of the brood fails to hatch. Cappings here and there are sunken and perforated at the centre. On opening one of these cells there will be found a dead larva lying on one side of the cell, somewhat shrunken, and of a brownish colour, varying all the way from a light pale brown to a dark brown. In the more advanced stages the brown is of the colour of a coffee-berry after being roasted. In the incipient stages the brown is of the colour of the coffee we drink, when greatly diluted with milk. But so far all these symptoms may be present as the result of chilled, over. heated, or pickled brood. But to determine whether it is the real ropy foul brood, run a toothpick into the dead larva and then draw it slowly out. If the maturated mass adheres to the end of the pick like spittle, stretches out from one-half to one inch, and finally the fine thread breaks when the pick is drawn back, it is probably a case of foul brood. With all other forms of diseased brood, with perhaps the exception of European foul brood, where the roping is never more than slight, this ropiness does not appear; but with foul brood it is invariably present. There is another symptom 
and that is the odour, while not exactly foul, resembles greatly that from a cabinetmaker's glue-pot; and when the disease is pretty well advanced in the hive, the odour will make itself manifest upon lifting the cover or quilt, even before exposing the brood. If other colonies are affected, and the disease spreads, it is probably American or ropy foul brood."

\section{European Foul Brood.}

The germs of this disease were first discovered in Europe, hence the name. The appearance of this form of foul brood is thus described :-

"Adult bees in affected colonies are not very active, but do succeed in cleaning out some of the dried scales. This disease attacks larvæearlier than does American foul brood, and a comparatively small percentage of the diseased brood is ever capped; the diseased larvæ which are capped over have sunken and perforated cappings. The larva when first attacked show a small yellow spot near the head and move uneasily in the cell; when death occurs they turn yellow, then brown, and finally almost black. Decaying larvæ which have died of this disease do not usually stretch out in a long thread when a small stick is inserted and slowly removed; occasionally there is a very slight 'ropiness,' but this never very marked. 'The thoroughly dried larvæ form irregular scales, which are not strongly adherent to the lower side-wall of the cell. There is very little odour from decaying larvæ which have died from this disease, and when an odour is noticeable it is not the 'glue-pot' odour of American foul brood, but more resembles that of soured dead brood. This disease attacks drone and queen larve very soon after the colony is infected. It is, as a rule, much more infectious than American foul brood and spreads more rapidly. European foul brood is most destructive during the spring and early summer, often almost disappearing in late sumimer and autumn."

\section{Pickled Brood.}

This is the name given to a disease of the brood about which very little is at present known. Many of the symptoms are very like those of European foul brood, but the cause of death is supposed to be starvation, excess of heat or cold, or poison in the food. We have seen that there may be a sudden stoppage of nectar at certain seasons; consequently, in a hive that is short of stores at such a time, thousands of the young must literally starve to death. In extremely hot weather, when ventilation is deficient, the inside temperature of the hive may become so hot as to cook the young larvæ; on the other hand, a sudden drop in temperature will cause the bees to contract their cluster, exposing many of the young so that they freeze to death. Then in the fruit-bloom season some ranchers spray before the blossoms fall with a poisonous solution, and, of course, the bees that visit such an orchard not only die of the poison, but frequently are able to empty their load into the cells before succumbing. The poisoned honey kills any brood to which it is fed.

We see, therefore, that the presence of dead brood in a hive demands instant consideration. The first question to be asked is, what is the likelihood of starvation? The condition of the stores should answer that. Next, has any one in the neighbourhood been spraying blossoms with a poisonous mixture? The bee-keeper should know by the season, the number of dying bees round the hive, and the habits of his neighbours. In the same way he will probably know the facts about recent temperatures. When the disease is due to any of these causes the bees in due course clean out the cells, and there is no trouble with subsequent brood. Should, however, neither starvation, heat, cold, nor poison account for the condition, or should the diseased brood continue or increase, then help should be solicited from the Department of Agriculture. As a diseased hive weakens, bees from other hives rob it of its stores, thus conveying the germs to all the hives in the vicinity. 


\section{ANNoyances.}

Complaint is made from certain regions that in some years wasps become so numerous in the autumn that by sheer numbers they can overcome the inmates of a hive and rob the stores. In all cases of robbing, whether by wasps or bees, narrow the entrance down to a space just wide enough to permit only one bee to pass at a time, so that defence will be very easy. A small bit of wood makes a good entrance block. The wasps that fly round in May are queens, so that every one killed then means a colony exterminated. A death at this time prevents thousands of lives in the fall.

\section{CHAPTER XIV.}

\section{Melting Wax.}

In an eight-frame hive the combs contain about 2 pounds of pure wax, but after several years' use they may weigh as much as four times the original weight. 'The increase is due to dirt in various forms. The cappings that are removed during extracting are almost pure wax, there being usually about 1 pound of wax to every 50 pounds of honey. Pure wax is always a marketable commodity in a fruit district and in every drug-store. In Victoria the latter pay 45 cents a pound for it. We therefore see that every scrap of comb is worth saving, so that it may be rendered at the end of the season. After making dozens of experiments, the writer believes that for the small apiarist the oven method is the best, and although it produces a little less than half of the available wax in old comb, it is as effective as any other process short of a regular wax-press. To pay the cost of the latter, one would have to work over about 100 pounds of old comb.

Take a bread-pan or similar dish and in one end at the bottom punch a hole a. quarter of an inch wide, any length. Fill it with comb and set it on the upper shelf of the oven, with a small stone under the unpunched end to tilt it up. On the lower shelf, so as to catch the drip, place another dish containing water. When the oven gets hot enough the wax will run from the old comb into the pan below. To make a nice cake of the wax, melt all the bits in a dish of water, then set aside to cool. A vessel with sloping sides like a lard-pail is good.

\section{Aiding a Weak Hive with more Bees.}

A hive that is strong in bees in early spring will attain great strength early in the season, while one that is weak will make very little headway, possibly may have a hard struggle to live. The laying capacity of the queen is limited by the number of larva the workers are able to care for; therefore, if we can add more bees to the colony the quicker will it develop. The skilful apiarist in che spring often does quite a business in transferring bees from one hive to another, but to be successful he must understand the limitations. In the first place it never pays to rob a medium strong colony to aid one that is weak. A hive that has every frame covered may be drawn upon, but never one that is weaker. Second, it it useless to give a frame of brood without nurse-bees to a weak colony, as the workers there are doing all they possibly can; but, on the other hand, it is risky to give old bees with a frame of brood, as these strangers may attack the queen, at least early in the season. Young bees are less liable to interfere.

To give young bees to a weak colony, go to a strong hive, select a frame containing brood, but be sure the queen is not on it-the only way to be certain is to see her-and shake the bees on to a large board in front of the hive. The old bees will fly lome in a few minutes, then shake those that remain on the alighting-board of the hive to be strengthened. They will crawl inside and be made welcomc. 
Some give aid by exchanging sealed brood, preferably hatching, for eggs. To do this, take a frame of sealed brood from the strong hive and shake off the bees, then carry it to the weak one and exchange it for a frame of eggs, as before shaking off the bees. In each case place the new frame in the centre of the cluster.

When the weak hive is fairly strong, say with bees on five or six frames, one need not hesitate to give it a frame of brood with adhering bees, provided it is not put next the frame on which the queen happens to be at the time.

To combine a queenless colony with another hive, in the evening, when flying has stopped, go tc the latter and remove the cover and quilts and spread a sheet of newspaper above the frames, punching a hole with a pencil in the centre of it, so as to give conmunication. Then lift the queenless hive and set it on top. The bees will gradually remove the paper and intermingle without fighting. In about a week remove the frames that are unoccupied, so as to make a compact brood-nest.

As a general rule, when nectar is coming in freely, the bees of a hive will welcome additions to their strength, but in times of dearth they will eject or kill the intruders. 


\section{LIST OF BEE-KEEPERS IN BRITISH COLUMBIA.}

Agassiz-Jos. Whelpton, F. Sinclair, J. C. McRae, Thos. Hicks, Albert Greyl, Wm. Mackie, E. Lambert.

Alberni-A. G. Service.

Armstrong-A. W. Hunter (Box 275), - Burnett, Alloyne Buckley, J. Simmington,

R. Daniels.

Arrow Park-Chas. L. Childe, A. Hemingway, Alf. Heffler.

Balcomo-R. H. Agur, A. Doherty.

Beaver Creek P. O.-Alex. Shaw, Donald McKenzie, R. W. Thompson.

Burnaby Lake-H. Ledger, C. F. Sprott.

Burton City-Mrs. Robson, Edw. Schram.

Cedar Cottage P. O.-Edward P. Flynn, John Benson, Wm. John Brewer.

Central Park-Mrs. M. J. Coburn (Park Avenue).

Chilliwack-H. L. Johnson, J. Brannick, Mrs. M. S. Davies (P. O. Box 229), Isaac

Kipp, Hy. Kipp.

Coburn-Parker Williams.

Colquitz-Ernest Etheridge, H. D. Van Decar.

Comox-H. Bourne, -- Smith (Little River).

Courtney-James McKenzie, Richard Creech.

Cranbrook-T. S. Gill, Wm. Hamilton (Box 93), Chas. Potvin, W. L. Whitney.

Creston-Walter V. Jackson.

Cumberland-Thomas Pierce.

Denman Island-Jas. Ormiston.

Dewdney-Alister Thompson, S. Smith, R. Gourlay, Fred. Newton.

Duncan-Mrs. Hy. Smith, - Duncan, - Price.

East Burnaby-Mrs. E. C. Morley, W. H. Lewis (Box 317).

East Sooke-T. Oldershaw.

Eburne-Henry Kacer.

Enderby-James Emery.

Epworth-Edward Flynn, W. G. Sutton.

Esquimalt_Jos. Robinson (Fraser Street), - Lea (Lampson Street), W. F. Corfield

(Head Street).

(xanges Harbour-J. T. Collins, H. Caldwell.

Glen Valley-Geo. R. Arthur.

Glenwood-G. Shelby-Hele.

Gordon Head- - Gray.

Grantham-Alex. Salmond.

Hall's Prairie-Wm. Brown, H. G. Lawrence, D. Brown \& Sons.

Harrison Mills-Anton Lambery.

Hazelmere-F. J. Hardwick, P. O. Green, H. Hamel.

Howser-H. R. Board, H. Hincks, Messrs. Matthews.

Hatzic-J. H. Lawrence, E. McTaggar't, A. McTaggart, Slack Bros., Hodson Bros.,

J. Edmons, T. Cattewood.

Kamloops-Smith Bros.

Kaslo-Archdeacon Beer, G. S. Fihle (Box 34).

Keating - - Young, Xavier Rey.

Kelowna-W. S. Fuller (Box 155), H. B. D. Lyons, James Harvey, Geo. Thompson, Chas. Lodge.

Keremeos-J. J. Armstrong.

Ladner-R. C. Ablott, J. Reagh.

Ladysmith-John Irvine.

Langley-Alex. Holding, Frank Baxter, - Briges.

Langley Prairie-Mrs. John Wilson, Geo. Blair, Geo. Trigg, - Savage.

Lytton-Alex. Lochore, Alf. Ruddock.

Malakwa-J. H. Johnson.

Maywood P. O., Victoria- G. F. Dunn, R. R. Watson, J. H. Hughes.

Mayne Island-James Bennett, - Padden, Miss Padden.

Metchosin-W. Fisher, J. Parker, J. D. Reid, C. Field, Stanley Clark, A. T. M. Inverarity (Box 407, Victoria).

Millstream-G. M. Bernard.

Milner-John Maxwell. 
Mission City-J. A. Catherwood, J. Mitehell, T. R. Smith.

Mount Tolmie-Robert Russell, James Townsend.

Nanaimo-Charles G. Stevens, Joseph Decon‘r, John Skinner, F. H. Jones.

Nelson-Charles Gansner (Box 187), D. La Bau, A. J. Laviolette.

New Denver-J. C. Harris.

Now Westminster-Wm. Anderson (Box 408), E. Stude, Frank Davies.

Okanagan Centre-H. N. Caesar.

Okanagan Landing-Miss Peters, Mrs. Leslie.

Peachland-W. E. Morsch.

Pender Island-A. H. Menzies.

Port Guichon-Felix Guichon.

Proetor-William Harg-Smellie.

Renata-E. L. Redhead.

Revelstoke-Rev. C. A. Procunier, Thos. W. Bradshaw (C. P. R.), Geo. G. Staffner, H. F. R. Smith, H. Cameron, B. A. Lawson, Geo. Laforme, W. Haner, G. Raleigh.

Rocky Point-Tom Parker.

Roseberry-S. Z. Brockmann.

Rossland-Edgar Charles (Box 114), James S. Gow (Box 74), Arehie MeMillan.

Rutland-Thos. Barber, - MeDonald.

Salmo-James F. Westby.

Sandwick-Rev. Thomas Menzies, Hugh Clark, W. H. Grieve, John Shopland, I.

Cliffe, T. Bridges, W. Dunean, S. J. Perry, Rev. Willimar.

Sardis-Jas. Higginson.

Seymour Arm-E'. N. Daniels.

Sidney-Chas. Armstrong.

Sooke-John A. Murray, John A. French.

South Vancouver-Mr. Pacey (Wilson Road and Pacey Avenue).

Strawberry Vale-Rob. Clark.

Summerland-F. J. Nixon (P. O. Box 3), Miss V. Cartwright, R. Pollock, M. Tait, B. H. Sherk, A. Fraser, W. H. Hayes, P. Thornber, A. Stewart, J. Gartell, Alf. Aveson (Box 38), F. W. Bentley (Box 108), B. H. sharp, H. Briston, T. Niven, J. Dunsdon, Dr. Sawyer, Rev. J. White, Geo. Sinclair.

'Trail-Thos. Heath.

Union Bay-Geo. HI. Roe.

Vancouver-J. B. Lee (2644 Manitoba Street), Norman N. Reid (1019 Davie Street), Geo. Schofield (1641 8th Avenue), Wm. Jefferson (1555 Westminster Avenue), M. J. Henry (3010 Westminster Road), Mrs. R. J. Fisher (1037 Denman Street), Wm. Rennie Seed Co., Herman M. Alpine (1550) 7th Avenue).

Vernon-Rev. R. J. Vaus, Arthur T. Kirkpatrick, E. Leonard Harris, C. M. Watson (Box 447), John Freeman, Rev. G. Kunke, Lloyd Quick, R. E. Tennant, John Kidston, J. Webster, T. A. Norris, - Watson.

Victoria-G. A. Borthwick (Drawer 664), - Brinkman (Washington Avenue), E. Fleming (Government Street), T. J. Evans (William Street, V. W.), D. J. Griffin (1121 Langley Street), W. H. Nelson (Brunswick Hotel), E. F. Robinson (417 Young Street), S. M. A. Savory (13 Broad Street), F. D. Todd (743 Market Strcet), J. R. Grice (4S Second Street), W. R. Palmer (Box 534), Miss E. C. Saunders (Victoria West), Arthur C. C. Stratford, A. J. Woodward (Ross Bay), 'Thos. Shotbolt (Druggist), W. Hardy (Catherine Street, V. W.).

Wellington-A. Willey, Jos. Carr.

Yale-Mrs. J. M. McQuarrie.

VICTORIA, B. C.:

I'rinted by Ricuard Wolrmxdrx, I.S.O., V.D., Printer to the King's Most Excellent Majesty. 1910. 




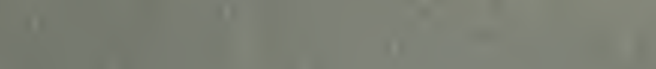

(1)

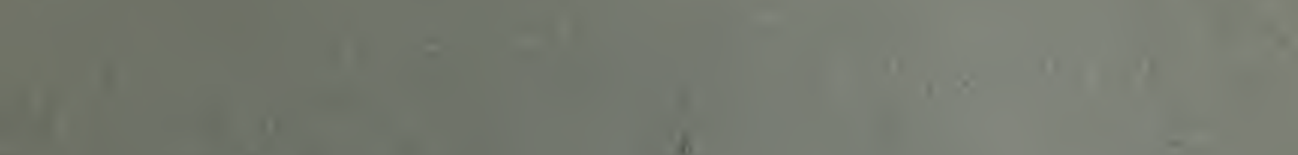
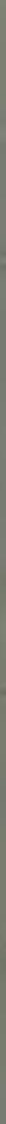

31

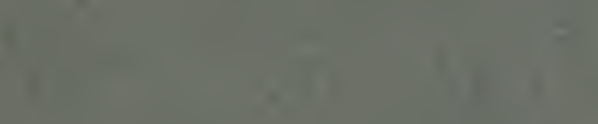

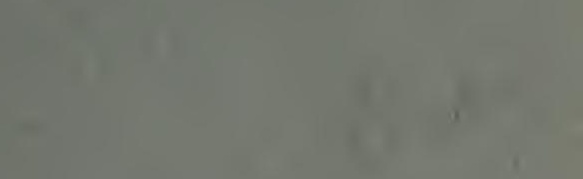

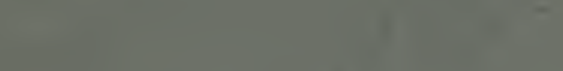

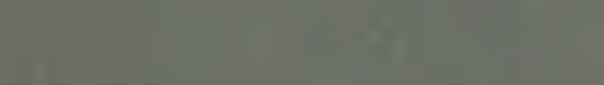

4iv $4 y^{2}=$

4.

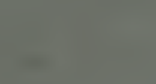

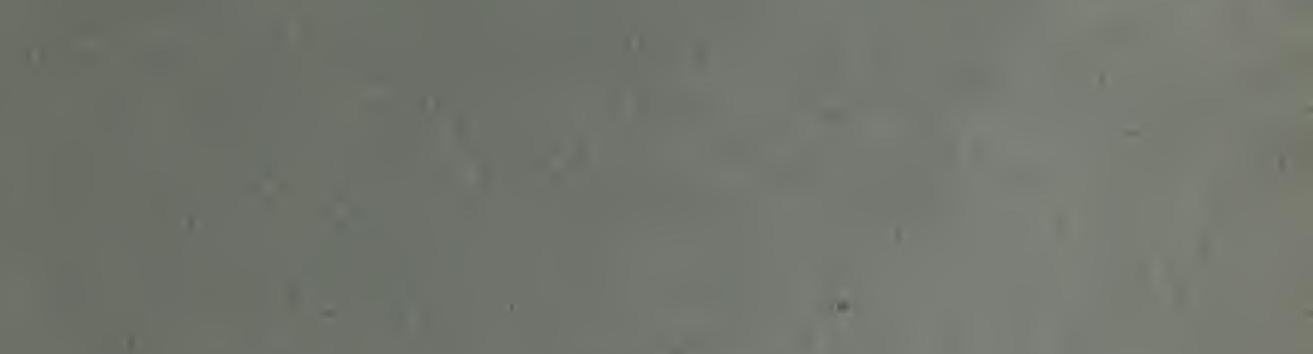

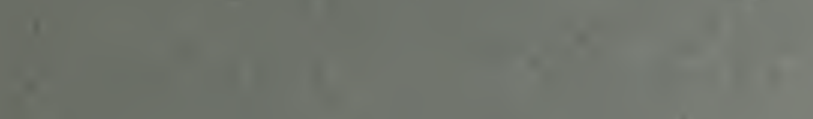





\section{N.259475}

$$
\begin{aligned}
& 5141 \\
& \text { 4 } 4 \\
& \text { no. } 30
\end{aligned}
$$

THE UNIVERSITY OF CALIFORNIA LIBRARY 
